$$
\text { DOE/OR/00033-T566 }
$$

MARK CARL BELK

Growth, life history, and species interactions of bluegill sunfish (Lepomis macrochirus) under heavy predation. (Under the direction of MICHAEL H. SMITH)

The purpose of this study was, first, to compare growth and life history characteristics of an unfished population of bluegill sunfish (Lepomis macrochirus) in the presence of an abundant predator population to characteristics exhibited by bluegills in typical southeastern U.S. reservoirs where the abundance of predators is reduced, but fishing is increased. The second objective was to determine if differences observed between populations were determined genetically or environmentally.

Par Pond is a nuclear reactor cooling reservoir with restricted public access. Bluegills in Par Pond grew faster, attained larger adult sizes, and matured about 2 years later and at larger sizes than bluegills in other southeastern reservoirs. Largemouth bass (Micropterus salmoides) in Par Pond were 3-4 times more abundant and 10$30 \%$ larger than bass in other reservoirs in the southeastern U.S. Differences in bluegill growth and reproduction appeared largely attributable to differences in abundance and size-structure of predators in these reservoirs.

Competition among bluegill sunfish and between bluegills and two other species of sunfish was evaluated experimentally in Par Pond. Growth rates of bluegills were unaffected by presence of other Lepomis species, but growth rates decreased with increasing bluegill density. However, 
growth rates of bluegills at densities corresponding to those found in the reservoir were high, and competition appeared to be unimportant at these densities. Growth rates of bluegills in vegetated refuge areas were about $1.5 \mathrm{X}$ higher than growth in open, risky habitats. Percent lipid content of bluegills was generally unaffected by treatments. In Par Pond, juvenile bluegills were found at relatively low densities and had high growth rates in refuge environments, indicating a strong lethal effect of predators on bluegill population dynamics.

Finally, to determine if variation in growth and age at maturity between Par Pond bluegills and other populations was genetically based or induced environmentally, I used "common-garden" experiments to compare Par Pond bluegills and bluegills from a local hatchery population. Growth was influenced strongly by resource level, but growth rate did not vary among populations. Nearly all bluegills in each population matured at one year of age in a common environment. Thus, variation observed in source populations must be attributable to differences in the environment between populations. Observed patterns of variation between populations were best explained by effects of predation.

INDEX WORDS: Predation, Competition, Life History, Age and Growth, Lethal and Nonlethal Effects, Bluegill Sunfish, Lepomis macrochirus, Phenotypic Plasticity, Size-selective Predation 


\title{
GROWTH, LIFE HISTORY, AND SPECIES INTERACTIONS \\ OF BLUEGILL SUNFISH (LEPOMIS MACROCHIRUS) \\ UNDER HEAVY PREDATION
}

by

MARK CARL BELK

B.S., Brigham Young University, 1985

M.S., Brigham Young University, 1987

\author{
A Dissertation Submitted to the Graduate Faculty \\ of the University of Georgia in Partial Fulfillment \\ of the \\ Requirements for the Degree \\ DOCTOR OF PHILOSOPHY
}

ATHENS, GEORGIA

1992

\section{DISCLAIMER}

This report was prepared as an account of work sponsored by an agency of the United States Government. Neither the United States Government nor any agency thereof, nor any of their employees, makes any warranty, express or implied, or assumes any legal liability or responsibility for the accuracy, completeness, or usefulness of any information, apparatus, product, or process disclosed, or represents that its use would not infringe privately owned rights. Reference herein to any specific commercial product, process, or service by trade name, trademark, manufacturer, or otherwise does not necessarily constitute or imply its endorsement, recommendation, or favoring by the United States Gr,vernment or any agency thereof. The views and opinions of authors expressed herein do not necessarily state or reflect those of the United States Government or any agency thereof. 
GROWTH, LIFE HISTORY, AND SPECIES INTERACTIONS OF BLUEGILL SUNFISH (LEPOMIS MACROCHIRUS) UNDER HEAVY PREDATION

by

MARK CARL BLK

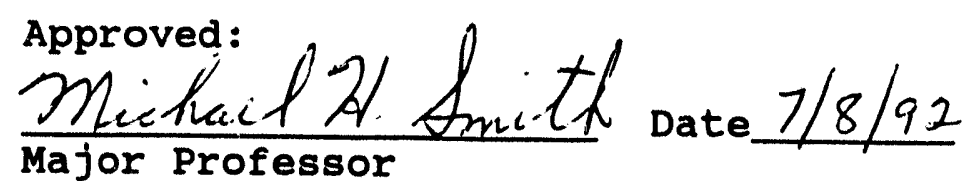

Approved:

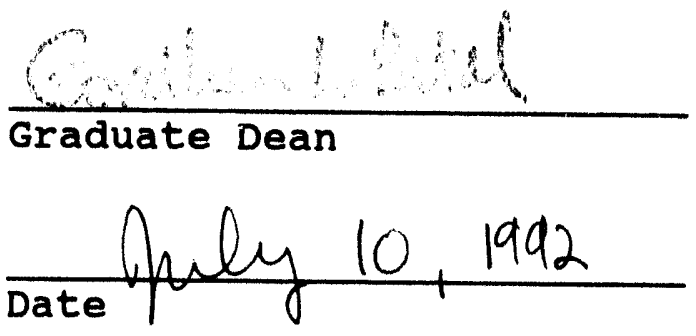




\section{DEDICATION}

With love to

Laura Ann Belk

and

Samuel and JoAnne Belk

who have endured the many inconveniences

associated with my fascination with the natural

world, and have helped and encouraged me during

the completion of this research. 


\section{ACKNOWLEDGMENTS}

Completion of this dissertation required not only logistic and technical support but also moral support and encouragement. My wonderful wife, Laura Ann Belk, provided a great deal of the needed support and encouragement, and I am grateful for her unwavering faith in me. I am grateful to my parents, Samuel and JoAnne Belk for encouraging my interest in the natural world, and for giving emotional support and financial support at times that I may pursue those interests.

Doctor Michael H. Smith, my major advisor, provided valuable guidance and direction in many aspects of this research. Mike allowed me to be independent in choosing and planning my research, but was always willing to help when I encountered seemingly unresolvable obstacles. The other members of my committee, H. Ronald Pulliam, Justin D. Congdon, Gary K. Meffe, and Robert J. Warren, all provided valuable suggestions for the research and helpful reviews of the manuscripts included in this dissertation.

To the many people at SREL, I. am sincerely grateful for technical help, manual labor in the field, and friendship. of particular help were Chuck Lydeard, Dana Winkelman, Paul Leberg, Susan McAlpine, Julie Wallin, Yvonne Van Alstine, 
Dave Schultz, Robert Fischer, Jay McArthur, Phil Dixon, Karen Kandl, Walter stevens, Warren stevens, Kevin Willis, Paul Johns, Jim Novak, Adrienne DeBiase, Ralph Mazenko, Harry Roczak, Louise Zweifel, and Andrea Seeley.

Special thanks go to R. Cary Tuckfield for providing valuable statistical advice and assistance, opportunity to collaberate on research, and help in the field when I was in dire need. Most importantly, he provided many insightful and inspiring conversations on our way to and from work for which my mind and spirit are eternally grateful.

This research was supported by contract DE-ACO9-76SROO819 from the U.S. Department of Energy to the Savannah River Ecology Laboratory, and was based on work performed in the Laboratory Graduate Participation Program under contract number DE-ACO5-760RO0033 between the U.S. Department of Energy and Oak Ridge Associated Universities. 


\section{TABLE OF CONTENTS}

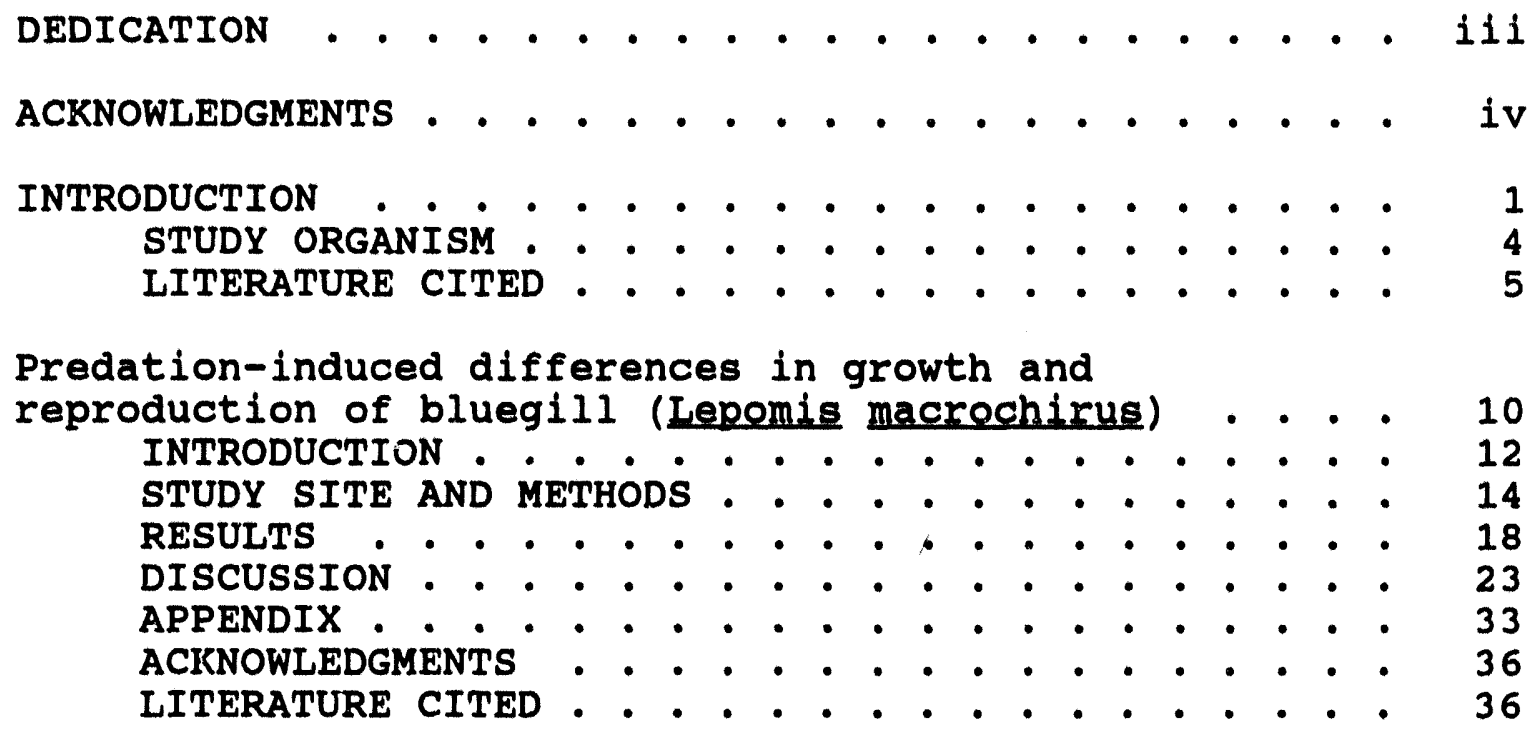

Competition among juvenile sunfishes (Lepomis spp.) under heavy predation . . . . . . . . . . . . . . 54 INTRODUCTION . . . . . . . . . . . . . . . 56 METHODS . . . . . . . . . . . . . . . 58 RESULTS ........................ 67 DISCUSSION . . . . . . . . . . . . . . . . . 10

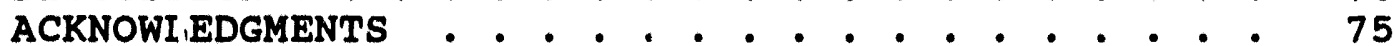
LITERATURE CITED . . . . . . . . . . . . . . 75

Variation in growth and age at maturity in bluegill sunfish (Lepomis macrochirus): genetic or environmental effects? . . . . . . . . . . 87 INTRODUCTION . . . . . . . . . . . . . . . . 89 MATERIALS AND METHODS . . . . . . . . . . . . . 92

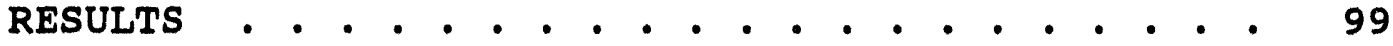
DISCUSSION . . . . . . . . . . . . . . . 100 ACKNOWIEDGMENTS . . . . . . . . . . . . . . . 106 LITERATURE CITED . . . . . . . . . . . . . . 107 CONCLUSION . . . . . . . . . . . . . . . . . . . 119 


\section{INTRODUCTION}

Predation can affect many aspects of prey ecology including community composition, population growth, individual growth and behavior, and life history characteristics (Brooks and Dodson 1965, Paine 1974, Sih et al. 1985, sih 1987, Reznick et al. 1990). What are the mechanisms whereby predators influence prey population dynamics? A review of the literature suggests two distinct ways (Kotler and Holt 1989): 1) directly via lethal effects that alter mortality rates and density (sih 1987, "trophiclink effect" sensu Miller and Kerfoot 1987), and 2) by nonlethal effects, such as altering prey behavior (e.g., habitat choice, diet, and movement patterns; "behavioral indirect effect" sensu Miller and Kerfoot 1987). Traditionally, lethal effects have received the greatest attention (sih et al. 1985). Lethal effects of predators on prey typically result in decreased density of prey, decreased potential for competition among prey, and increased individual prey growth rates (Paine 1974, Kotler and Holt 1989). More recently, nonlethal effects of predators on prey have increasingly been demonstrated (Miller and Kerfoot 1987). Nonlethal effects, such as behavioral responses of prey to predators, can result in 
increased densities of prey occupying refuge habitats, leading to increased competitive effects among prey, and decreased individual growth rates of prey (Werner et al. 1.983, Mittlebach 1988, Werner and Hall 1988). Thus, lethal and nonlethal effects of predators can have opposite influences. Although both lethal and nonlethal effects of predators have been demonstrated, little information is available on the relative magnitude of these two effects in natural populations (Mittlebach and Chesson 1987). Also, little is known about what characteristics of predator populations might bias toward lethal or nonlethal pathways of influence.

Chapter 1 compares prey populations in the presence of an abundant predator population to prey populations with lower levels of predators. In this chapter I evaluate predicted effects of predators to determine the relative magnitude of effects via lethal and nonlethal pathways. Chapter 2 further explores the effects of predators by experimentally evaluating inter- and intraspecific interactions among prey in a high predation environment. As outlined above, the potential for competiton among and within prey species depends on whether lethal or nonlethal effects of predators are most influential. strong competitive effects among prey in refuge habitats may indicate that nonlethal effects of predators are most important, whereas, lack of competitive effects among prey 
suggests a strong lethal effect of predators (Mittlebach and Chesson 1987, Werner and Hall 1988).

Chapters 1 and 2 focus on effects of predators on patterns of growth and mortality of prey; predation also can cause changes in life history characteristics of prey, such as age at maturity (Crowl and Covich 1990, Reznick et al. 1990). Phenotypic differences in life-history characteristics observed among populations can result from genotypic variation and/or from the effect of environmental variation on a plastic phenotype. Genotypic differences can arise as a result of adaptation to local selective pressures that vary among populations (Endler 1986). However, in environments where selective pressures are variable in direction and magnitude, plastic phenotypes that respond to the immediate environment can be favored selectively (Caswell 1983, Kaplan and Cooper 1984, Via and Lande 1985). Determining which of these factors accounts for observed population variation is an important theme in evolutionary biology (Endler 1986).

Chapter 3 is an experimental evaluation of the basis of phenotypic variability observed among prey populations experiencing selective predation for different size-classes. "Common-garden" experiments were used to determine whether growth rate and age at maturity differed genetically among populations. 


\section{STUDY ORGANISM}

The bluegill sunfish (Lepomis macrochirus) was chosen as the experimental organism. Bluegills and other Lepomis species are widely distributed in freshwater systems in the U.S. and have been introduced in many places throughout the world (Lee et al. 1980). They often are dominant members of the fish fauna both in terms of numbers and blomass (Mittlebach 1988). Because of their wide geographic range and abundance, bluegills are among the most popular of gamefishes, thus making them economically important to many fisheries (Trautman 1981).

Bluegills feed on a variety of zooplankton species and benthic macroinvercebrates (Carlander 1977). They can significantly affect the abundance and size-structure of their prey in some habitats (Mittlebach 1988). Bluegills, in turn, are preyed upon by a variety of aquatic and terrestrial predators, especially in small size-classes (Carlander 1977). Because of their abundance and trophic position as both predator and prey, bluegills are ecologically important members of the fish community in most habitats where they occur.

Bluegill populations are composed of many different size-classes of individuals. Habitat use, diet, potential predators, and reproductive success of bluegills all vary with individual size (Gross 1979, Werner and Hall 1988). In response to the threat of predation, small bluegills occupy 
structurally complex habitats. As bluegills grow to invulnerable sizes, they shift to more open habitats and corresponding open-water, or benthic prey (Werner et al. 1983, Mittlebach 1984). Bluegills nest in open colonies where males compete to establish and maintain nests and to attract females (Gross 1979). Large males are competitively dominant, and also enjoy increased mating success relative to small males (Gross 1982). Some small males adopt alternate reproductive behaviors, such as sneaking, or female mimicry, and gain some reproductive success (Gross 1979, Dominey 1980, Gross and Charnov 1980). Such sizestructured variation makes bluegills good organisms for the study of ecological and evolutionary questions relating to predator-prey interactions, reproductive behavior, and lifehistory characteristics (Werner and Gilliam 1984). Because of their economic and ecological importance and their wide availability, bluegills have been studied extensively from several different perspectives, thus making comparative and experimental studies such as this one possible.

\section{LITERATURE CITED}

Brooks, J.L., and S.I. Dodson. 1965. Predation, body size, and the composition of plankton. Science 150:28-35. Carlander, K.D. 1977. Handbook of Freshwater Fishery Biology, Volume 2. Iowa State University Press, Ames, Iowa. 
Caswell, H. 1983. Phenotypic plasticity in life-history traits: demographic effects and evolutionary consequences. Am. Zool. $23: 35-46$.

Crowl, T.A., and A.P. Covich. 1990. Predator-induced lifehistory shifts in a freshwater snail. science 247:949951 .

Dominey, w.J. 1980. Female mimicry in male bluegill sunfish - a genetic polymorphism? Nature 284:546-548.

Endler, J.A. 1986. Natural selection in the wild. Princeton Univ. Press, Princeton, NJ.

Gross, M.R. 1979. Cuckoldry in sunfishes (Lepomis: Centrarchidae). Can. J. Zool. 57:1507-1509.

----. 1982. Sneakers, satellites and parentals:

polymorphic mating strategies in North American sunfishes. Z. Tierpsychol. $60: 1-26$.

Gross, M.R., and E.L. Charnov. 1980. Alternative male life histories in bluegill sunfish. Proc. Nat. Acad. Sci., U.S.A. 77:6937-6940.

Kaplan, R.H., and W.S. Cooper. 1984. The evolution of developmental plasticity in reproductive characteristics: an application of the "adaptive coinflipping" principle. Am. Nat. 123:393-410.

Kotler, B. P., and R. D. Holt. 1989. Predation and competition: the interaction of two types of species interactions. Oikos 54:256-260. 
Lee, D.S. 1980. Lepomis macrochirus (Rafinesque), Bluegill. Page 597 in D.S. Lee, et al. eds. Atlas of North American Freshwater Fishes. N.C. State Mus. Nat. Hist., Raleigh, N.C.

Miller, T. E., and W. C. Kerfoot. 1987. Redefining indirect effects. Pages 33-37 in W. C. Kerfoot and A. Sih eds. Predation: Direct and Indirect Impacts on Aquatic Communities. University Press of New England, Hanover, New Hampshire.

Mittlebach, G. G. 1984. Predation and resource partitioning in two sunfishes (Centrarchidae). Ecology $65: 499-513$.

1988. Competition among refuging sunfishes and effects of fish density on littoral zone invertebrates. Ecology 69:614-623.

Mittlebach, G. G., and P. L. Chesson. 1987. Predation risk: indirect effects on fish populations. Pages 315332 in W. C. Kerfoot and A. Sih eds. Predation: Direct and Indirect Impacts on Aquatic Communities. University Press of New England, Hanover, New Hampshire.

Paine, R.T. 1974. Intertidal community structure. Experimental studies on the relationship between a dominant competitor and its principal predator. Oecologia 15:93-120. 
Reznick, D.A., H. Bryga, and J.A. Endler. 1990. Experimentally induced life-history evolution in a natural population. Nature 346:357-359.

Sih, A. 1987. Predators and prey lifestyles: an evolutionary and ecological overview. Pages 203-224 in W. C. Kerfoot and A. Sih eds. Predation: Direct and Indirect Impacts on Aquatic Communities. University Press of New England, Hanover, New Hampshire. Sih, A., P. Crowley, M. McPeek, J. Petranka, and K. strohmeier. 1985. Predation, competition, and prey communities: a review of field experiments. Ann. Rev. Ecol. Sys. 16:269-311.

Trautman, M.B. 1981. The Fishes of Ohio. Ohio state University Press, columbus, Ohio.

Via, S., and R. Lande. 1985. Genotype environment interaction and the evolution of phenotypic plasticity. Evolution 39:505-522.

Werner, E. E., and D. J. Hall. 1988. Ontogenetic habitat silifts in bluegill: the foraging rate-predation risk trade-off. Ecology 69:1352-1366.

Werner, E. E., and J. F. Gilliam. 1984. The ontogenetic niche and species interactions in size-structured populations. Ann. Rev. Ecol. Sys. 15:393-425. Werner, E. E., J. F. Gilliam, D. J. Hall, and G. G. Mittelbach. 1983. An experimental test of the effects 
of predation risk on habitat use in fish. Ecology 64 : 1540-1548. 
Predation-induced differences in growth and reproduction of bluegill (Lepomis macrochirus) ${ }^{1}$

'Belk, M.C. and L.S. Hales, Jr. Submitted to Copeia, 3/27/92. 
Abstract. Predators can have both ecological and evolutionary effects on growth and reproduction of prey. Few studies have compared effects of predation across a wide range of predator abundance and sizes. We compared growth and size/age at maturity of bluegill sunfish (Lepomis macrochirus) in an unfished reservoir (Par Pond, South Carolina U.S.A.) to growth and size/age at maturity of bluegills in reservoirs which are fished. Largemouth bass (Micropterus salmoides) in Par Pond were 3-4 times more abundant and 10-308 larger than bass in other reservoirs in the southeastern U.S. Bluegill in Par Pond grew faster and attained larger adult sizes than bluegill in other populations. Par Pond bluegill were about 2 years older and $100 \mathrm{~mm}$ longer at maturity than bluegill in other southeastern U.S. reservoirs. Bluegill in Par Pond began reproducing at about the same size at which they outgrew the threat of predation (about $190 \mathrm{~mm}$ total length). Differences in bluegill growth and reproduction appeared largely attributable to differences in abundance and sizestructure of predators in these reservoirs. Effects of high levels of natural predation on growth rates and reproduction of bluegill in this study were different from the effects of predation at low levels as studied in other systems. 
INTRODUCTION

Predation can affect many aspects of prey ecology including community composition, population growth, and Individual growth and behavior (Brooks and Dodson, 1965; Paine, 1974; sih et al., 1985; sih, 1987). In sizestructured populations, individual growth rates are an important determinant of fecundity and survivorship (Werner and Gilliam, 1984). Thus, predation can influence prey populations directly by removing individuals, and also by changing individual growth rates (sih, 1987).

Predation has been reported to cause both increased individual growth rates in prey due to reductions in prey density (Forsythe and Wrenn, 1979; Morin, 1983, Wilbur, 1987), and decreased individual growth rates in prey due to behavioral changes in habitat use and activity patterns (Wilbur, 1972; Werner et al., 1983; Werner and Hall, 1988;

Skelly and Werner, 1990; Skelly, 1992). Additionally, studies dealing with foraging return rates under predation risk have shown a decrease in energy gain compared to predator-free foraging returns (Stein and Magnuson, 1976; Gilliam and Fraser, 1987; Abrahams and Dill, 1989; Gotceitas and Colgan, 1990), presumably leading to decreased individual growth. Few studies have addressed the change in individual prey growth rates that might occur under varying abundances of predators. 
Because timing of first reproduction can be age or size dependent (Poljcansky, 1983), changes in growth rate induced by predation can alter individual reproductive schedules. If prey must use risky habitats to reproduce, then predation can directly influence the size or age at first raproduction by confining vulnerable size classes of prey to habitat unsuited for reproduction, or by reducing reproductive behavior in risky habitats (Magnhagen, 1990; J. F. Gilliam pers. comm.). By altering size-specific mortality rates predation can also influence the expression of alternative reproductive behaviors (Gross, 1991). We know of no empirical studies relating timing of first reproduction in individuals to size-structure and abundance of predator populations.

The above-mentioned studies suggest that the effects of predators on prey are complex, and they can vary in magnitude and sign. We asked the question "does growth rate and age at maturity of bluegill sunfish (Lepomis macrechirus) vary with density and size of predators?" We describe differences in growth and maturation of bluegill between a popuiation experlencing heavy fuvenile mortality from natural predators and populations with increased levels of adult mortality. We present evidence that the effect of predation on growth rates and timing of reproduction depends on the density of predators. Based on these observations we formulated a graphical model of the effect of predation on 
growth rates of prey over a range of predator densities. Lastly, we discuss the possibility that life history traits of bluegill result from size-specific predation.

\section{STUDY SITE AND METHODS}

Bluegill were collected from April to August 1989 in Par Pond (PP), a 1069-ha nuclear reactor cooling reservoir located on the Savannah River site near Aiken, south Carolina. Par Pond was constructed in 1958 and has never been open to public fishing. The fish fauna of PP is typical of southeastern U.S. reservoirs (Bennett and McFarlane, 1983). Because PP has never been fished, it provides an uncommon opportunity to study interactions of unexploited fish populations.

Bluegill were collected by angling and electroshocking (Smith-Root, boat-mounted electroshocker). It was necessary to use both methods to collect the entire size range of bluegill present in PP. Total length (TL, in mm), mass (to nearest $0.01 \mathrm{~g}$ ), maximum body depth (in $\mathrm{mm}$ ), and reproductive status (spawning or nonspawning) were recorded for each fish.

Because fish in PP were collected during the spawning season (April through August), gross examination of gonads was used to determine reproductive condition (Snyder, 1983). To determine size at first reproduction, the proportion of reproductively active $f$ ish was calculated in each $20 \mathrm{~mm} \mathrm{size}$ 
interval. The size interval where more than half of the flsh were reproductively active was considered the average size at first reproduction (Trippel and Harvey, 1991). In some bluegill populations, alternative reproductive behaviors are exhibited by a percentage of adult male bluegill. Parental, nest-guarding males are large and mature later than cuckolder males which mature early at small sizes. Frequency distributions of body sizes of reproductively active males in populations with both types of males are bimodal (Dominey, 1980; Gross and Charnov, 1980). Accordingly, absence of small reproductive males, unimodal distribution of adult male body sizes with a large mean body size, and small variance would indicate a lack of males exhibiting alternative reproductive behaviors (M. Gross pers. comm.). To detect the presence of male bluegill in PP exhibiting alternative reproductive behaviors the size distribution and minimum size of reproductive males were determined.

Ages of fish were determined by counting otolith annuli, which have been validated previously (Hales and Belk, in press). Size at age was back-calculated from 
otolith measurements using the following formula (modified Fraser-Lee method, Campana, 1990):

$$
L_{x}=L_{0}+\left(L_{c}-L_{0}\right)\left(R_{x}-R_{0}\right) /\left(R_{c}-R_{0}\right)
$$

where $L_{x}$ is estimated TL at age $x, L_{c}$ is length at capture, $R_{x}$ is otolith radius at age $x$, and $R_{c} 18$ otolith radius at capture. Io is estimated length at swim-up $(6 \mathrm{~mm}, M$. Belk, pers. obs.), and $R_{0}$ is estimated otolith radius at swim-up $(0.04 \mathrm{~mm}$, measured from otoliths). An age-growth curve was generated by averaging back-calculated sizes at each age. Annual mortality rates $\left(A=1-e^{-2}\right.$, where $z=$ the slope of the regression of In frequency on flsh age; assuming a stable age-distribution) of bluegill from PP were calculated from catch curves (Ricker, 1975). Because of the difference in growth rate between juvenile (ages I-III) and adult (ages IV-IX) fish in PP, mortality estimates were calculated separately for these age classes. Mortality estimation of young fish in PP was problematic, because some Age III fiah were not vulnerable to collection by shocking. To be conservative, we used a value known to be smaller and one thought to be larger than the true number of Age III fish to generate upper and lower limits of the mortality estimate for young fish. The average of these two estimates was used as the mortality estimate.

size- and habitat-specific density estimates of $\mathrm{fish}$ in large reservoirs are difficult to obtain. par pond has 
relatively steep sloping sides, and vegetated refuge areas occured in water up to $4 \mathrm{~m}$ deep. These conditions made seining or use of a drop trap to estimate density nearly impossible. Consequently, density was estimated using a boat-mounted electroshocker to obtain sequential removal samples from a defined area. Small, isolated beds of eelgrass (Vallieneria americana) were intensively shocked for a standard amount of time (5-15 min, time varied depending on size of bed), and the procedure was repeated three times for each bed. Total population size was estimated using the generalized removal model available in the computer program CAPTURE (White et. al., 1982). The model allows differential capture probabilities for successive trials. Ten beds of vegetation were sampled (chosen from all major areas of the reservolr except the arm receiving thermal effluent), and density estimates were averaged for an overall estimate of juvenile bluegill density. To quantify vulnerability of bluegill to predation in PP, largemouth bass (Micropterus salmeldes) were captured via angling and their TL and gape were measured. Additional information on size-structure and abundance of bass in PP was obtained from previous studies.

For comparison to PP, we compiled data from published studies on growth and reproduction of bluegill in typical, public reservoirs. Because of intense fishing pressure, public reservoirs have a relatively low abundance and small 
size-structure of natural predators (e.g., largemouth bass). Growth rates in bluegill vary with latitude (Carlander, 1977), so we restricted comparisons to reservolrs located in the southeastern U.S. We collected data on bluegill sizeat-age (growth curves), size and age at first reproduction, and mortality rates, and largemouth bass size-structure and abundance. Because some data were not available from all reservoirs, we attempted to characterize the complete range of variation in growth and reproductive parameters of bluegill found in public reservoirs in the southeastern U.S. only growth curves constructed with sample sizes $>100$ were used. We found 30 growth curves from 25 reservoirs located in the southeastern U.S. that had acceptable sample sizes (See Appendix for references).

Gape size limits the size of prey bass can consume. Therefore, the inner width of the gape was considered to correspond to the body depth of the maximum size of bluegill a bass could consume (Lawrence, 1957; Hambright, 1991). The TL of bluegill that could be eaten by a bass of a given gape size was calculated by regressing bluegill body depth on TL. In all comparisons, statistical significance was assumed when $P<0.05$.

\section{RESULTS}

Growth.-- Bluegill collected in PP ranged from 1-9 years in age and 37-278 $\mathrm{mm}$ TL. Bluegill in PP grew faster and 
attained larger adult sizes than bluegill in other reservoirs (Fig. 1). The growth curve for PP showed a distinct two-phase pattern with a break point occurring at age IV. Bluegill grew rapidly until they were about $240 \mathrm{~mm}$ TL, at about age IV, after which little growth occurred (Fig. 1, Table 1). Annual growth increments of bluegill in PP before age IV were significantly higher than growth increments of bluegill in typical southeastern reservoirs, after age IV growth increments of bluegill in PP were significantly lower than growth of bluegill in other reservoirs (Fig. 2) No significant differences existed in length-at-age between males and females at ages I-V (ANOVA, P>0.48; length at ages VI-IX was not tested due to small sample sizes).

Growth of bluegill in public reservoirs is characterized by gradually decreasing growth rates as age increases (Fig. 1). Maximum age of bluegill in the sample of public reservoirs included for comparison of growth rates ranged from 3 to 7 years (median $=5$ years). Annual growth increments during the first three years were distinctly lower than in PP (Fig. 2). Maximum size of adult bluegill in public reservoirs seldom exceeded $200 \mathrm{~mm}$ TL (Fig. 1). Five growth curves were from reservoirs that received thermal effluent. Growth of bluegill in these reservoirs was similar to growth in reservoirs without thermal influences. 
Reproduction. -- Bluegill in PP became reproductively active at a relatively large size and old age compared to other populations in southeastern U.S. reservoirs (Fig. 1). Bluegill less than $175 \mathrm{~mm}$ TL were seldom reproductively active. Between 175 and $215 \mathrm{~mm}$ TL they began reproduction, and above $235 \mathrm{~mm} \mathrm{TL}$ all were mature (Fig. 3). The smallest reproductive male was $207 \mathrm{~mm} \mathrm{TL}$. Distribution of TL of reproductive males was unimodal with mean $=257 \mathrm{~mm}$ and $S D=$ $14.5(\mathrm{~N}=67)$; TL of reproductive females also was unimodally distributed with mean $=243 \mathrm{~mm}$ and $S D=31.9(N=46)(F i g .3)$.

In comparison, bluegill in fished southeastern U.S. waters matured at smaller sizes and usually younger ages. First reproduction typically occured at 1-2 yrs. and 58-112 min TL (Fig. 1, Carlander, 1977, and references therein).

Mortality and Density. -- Mortality estimates for young bluegill (ages I-III; annual mortality $=67 \%$ ) were higher than estimates for old bluegill (ages IV-IX; annual mortality $=53 \%$ ) in PP. Estimates of mortality rates for juvenile bluegill in other reservoirs are rare; however, estimated annual mortality of bluegill ages I-III in Russell reservoir, a public reservoir located on the border between Georgia and South Carolina, was $53 \%$ (Catch-curve analysis; M. Belk, unpubl.). Estimated annual mortality of juvenile bluegill from numerous experimental ponds in Alabama was about 25\% (Swingle, 1951). Annual mortality rates for 
bluegill over ages III-IV from midwestern lakes and reservoirs averaged $78 \%$ (range 57-99\%; Carlander, 1977, and references therein).

Average density of juvenile bluegill in PP derived from electroshocking removal methods was 0.52 bluegill/m $\mathrm{m}^{2} \quad(n=10$, range $=0.05-1.3)$. Habitat- and size-specific estimates of bluegill density are unavailable for southeastern U.S. reservoirs. Densities of juvenile bluegill in the littoral zone of Lawrence Lake, Michigan averaged $1.6 \mathrm{blueg} 111 / \mathrm{m}^{2}$ (range $=0.5-2.4 ;$ Mittlebach, 1988).

Predator size-structure and abundance. -- Because PP is not open to fishing, density of bass is high and average size of bass is relatively large. Catch rates, via angling (by researchers), for bass in PP range from about 3 to 8 bass/hr. (Gibbons et al., 1972; M. Belk, unpubl.). Bass in PP average about $420 \mathrm{~mm}$ in TL and $0.84 \mathrm{~kg}$ in mass (Gibbons et al., 1978; Gilbert and Hightower, 1981). Density of bass in PP > about $300 \mathrm{~mm}$ TL, estimated by mark-recapture was 39$50 \mathrm{bass} / \mathrm{ha}$ (Gilbert and Hightower, 1981).

Typical catch rates for bass in fished, southeastern reservoirs range from 0.07 to $0.52 \mathrm{bass} / \mathrm{hr}$. (Martin and Hess, 1984; Beisser, 1989; Evans, 1989). Average size of bass in these reservoirs, estimated from creel surveys, is about the same as in PP; however, minimum size-limits of 300-355 mm TL are enforced on most of these reservoirs. 
Average size from electroshocking data was from $300-380 \mathrm{~mm}$ TL (Ager, 1988; Nash et al., 1989; Germann and Bunch, 1990). Using catch rate as an estimate of density, bass in PP were roughly 10 times more abundant and about 10-308 larger than bass in other reservoirs.

Average standing crop of largemouth bass for U.S. reservoirs was estimated at $10 \mathrm{~kg} / \mathrm{ha}$ (Jenkins, 1975). Average standing crop of bass in 22 public reservoirs in Georgia was $11.2 \mathrm{~kg} / \mathrm{ha}$ (range $4.5-33.6 \mathrm{~kg} / \mathrm{ha}$; Weaver 1981). Standing crop of bass in PP was about $36 \mathrm{~kg} / \mathrm{ha}$ (multiplying density times average mass; Paller and Saul, 1985). Using standing crop as a comparison, assuming roughly equal Individual mass, bass appear to be at least 3-4 times more abundant in PP than in typical U.S. reservoirs. Because catch rates can be influenced by variation in vulnerability of bass among populations, standing crop, which is not based on vulnerability, may provide a better estimate of the relative difference in predator density between fished and unfished systems. Either way, bass in PP are clearly more abundant and larger than bass in other reservoirs.

Bluegill vulnerability. -- Because of djfferences in predator size-structure among PP and other reservoirs, size at which bluegill escape predation differed markedly. Mean bass gape size in PP was $60 \mathrm{~mm}$ ( $S D=9.5 \mathrm{~mm}, \mathrm{~N}=64$ ). Bluegill that could be eaten by bass with gapes $\geq$ the mean 
gape size, +1 or +2 SD respectively, were 151,171 , and 192 mm TL. Therefore, bluegill in PP do not outgrow their major predator until they attain a relatively large size. Due to their smaller average size (mean $\mathrm{TL}=300-380 \mathrm{mril}$ ), bass in public reservoirs have mean gape sizes from about 43-54 mm, corresponding to bluegill from 108-136 mm TL. Thus, bluegill in public reservoirs consistently outgrow the threat of predation at smaller sizes.

\section{DISCUSSION}

Growth. -- Phenotypic differences in growth patterns of bluegill between populations could result from 1) differences in per capita resource availability, or 2) differences in energy allocation (between growth and reproduction) in individuals. Per capita resource availability is dependent on density of conspecifics and other competitors, and on overall productivity of the habitat. Differences in the pattern of energy allocation could result from a phenotypically plastic response to differences in the environment, or from genetic differences between populations. We consider each of these possibilities to determine whether they are consistent with observed differences in bluegill populations.

Productivity of reservoirs is determined by nutrient content of water and sediments and by temperature. Primary productivity in PP at $444 \mathrm{mg} \mathrm{C}_{1}\left(\mathrm{~m}^{2}\right)^{-1}$, day ${ }^{-1}$ is intermediate 
to values for other lakes and reservolrs in the southeastern U.S. that range from 101 to $2578 \mathrm{mg} \mathrm{C}\left(\mathrm{m}^{2}\right)^{-1}$, day ${ }^{-1}$ (Wilde 1985), suggesting that overall abundance of resources in PP are not inordinately high. In contrast, abundance of predators varies greatly between PP and other reservoirs. Largemouth bass are about 3-4 times as abundant and 10-30\% larger than bass in other reservolrs. Heavy predation could decrease densities of juvenile bluegill leading to increased per capita resource availablilty, and increased growth rates.

If predation is responsible for the unique growth pattern of bluegill in PP, densities of fuvenile bluegill should be low and mortality rates high relative to those of fish in reservoirs with less abundant predator populations. Unfortunately, density and mortality estimates for juvenile bluegill in other southeastern reservoirs are generally unavailable for comparison. The few estimates available in the literature suggest that juvenile bluegill densities in PP $\left(0.52 \mathrm{fish} / \mathrm{m}^{2}\right)$ are relatively low, and mortality estimates (67\% annual mortality) are relatively high; however, a strong comparison is not possible.

Differences in growth patterns of bluegill between populations could be due to differences in energy allocation in individuals. Individuals that mature at smaller sizes must allocate resources to reproduction at the expense of growth, leading to a reduction in later growth rates 
relative to individuals that did not reproduce. Age and size at first reproduction can be influenced by ize- or age-specific mortality rates (Law, 1979; Michod, 1979), which in turn are influenced by the abundance of sizeselective predators. Accordingly, differences in growth patterns between PP and other reservoirs could be due to differences in age and size at first reproduction and the corresponding trade-offs in energy allocation. In PP, high juvenile bluegill mortality caused by abundant predator populations, coupled with low mortality of adult bluegill, due to lack of fishing by humans, would favor larger size (older age) at maturity, allowing rapid growth for a longer time. In other reservolrs, mortality of fuvenile bluegill would be reduced because of less abundant predator populations, but mortality of adult bluegill would be increased due to fishing by humans. Such a combination would favor decreased size and age at reproduction, and a corresponding decrease in growth rate at smaller sizes.

The most obvious difference between PP and other reservoirs is the abundant population of predators in PP. It appears that predation could account for differences in growth either by reducing prey densities, thus increasing per capita resource availability, or by altering sizespecific mortality rates, thus leading to delayed maturity in PP bluegill. However, because of the comparative nature of this study, other factors, both those we have discussed 
and possible unknown influences, could influence growth of bluegill, and can not be entirely ruled out.

Effect of predators on growth rates. -- Growth rates of Age I-IV bluegill in PP were considerably higher than in other populations, and the? approached the maximum reported for the species (Carlander, 1977). Bluegill in PP are vulnerable to predation until they reach a large size.

In previously studied systems, bluegill become invulnerable to predators at a much smaller size (about 60$100 \mathrm{~mm}$ TL; Werner and Hall, 1988). In these aystems, predators are less abundant, and the prey population is not significantly reduced by predation (Prey removal by predators is actually compensated for in some experiments, e.g., Werner et al., 1983.). However, predators do confine prey to vegetated refuge habitats. Densities of small bluegill are high, and competition in refuge areas decreases Individual growth rates (Mittlebach, 1988; Werner and Hall, 1988). Growth rates of prey appear to be related to sizestructure or abundance of predators.

We propose a conceptual model to explain the effect on prey growth rates as abundance and/or size-structure of the predator population changes (Fig. 4). When predators are scarce or relatively ineffective (a.g., small gape size relative to prey size), the proportion of the prey population killed by predators is small (Swingle, 1951). In 
such systems, prey are resource-limited and habitat shifts in response to the presence of predators increase competition causing a reduction in growth rate in vulnerable 12e classes of prey (Mittlebach, 1988). As predator density and ize increase, larger size classes of prey become vulnerable and are confined to refuge habltats (Werner and Hall, 1988), further reducing growth rates. with further increases in predator density and size, predation begins to decrease prey density and a balance is achieved between positive and negative effects on prey growth. As predator density and size increase further, prey are at 111 confined to refuge habitats, but decreased prey densities preclude strong density-dependent effects (Swingle, 1951). At extremely high predator densities, prey densities are relatively low, but individual growth rates of vulnerable sized prey probably approach the maximum possible.

Par Pond represents the conditions of high predation and high prey growth rates (right side of the model, Fig. 4), whereas other studied systems (Werner and Hall, 1988) represent conditions of low predation and low prey growth rates due to behavioral responses to predators (left side of the model, Fig. 4).

Repreduction. -- Bluegill in PP matured about 1-2 yrs. later and at about $80 \mathrm{~mm}$ larger TL than bluegill in other 
reservoirs (Fig. 1). In PP, ize at first reproduction was closely tied to the size at which bluegill were no longer vulnerable to predators. In other reservolrs, size at flrst reproduction did not appear to be related to the size of predators, but, once again, density of bass was relatively low.

High densities of predators could constrain reproduction in two ways. First, for organisms that must use risky habitats during reproduction, threat of predation may directly limit the size of individuals that can reproduce. Blueglil nest in large, open colonies (Gross, 1979), where bass often are present (M. Belk, pers. obs.). Small bluegill experience greatly increased mortality rates in open habitats in PP (M. Belk, unpubl. ms.); thus, attempting to reproduce may be too costly. Second, organisms must allocate energy to the competing demands of maintenance, storage (e.g., lipids), growth, and reproduction. Individual that allocate energy to reproduction, at the expense of growth, increase the time they are vulnerable to predation. High rates of predation on fuveniles could selectively favor individuals that put avallable energy into growth until they outgrow the threat of predation, then shift to reproduction (a.g., crowl and Covich, 1990; Reznick and Endler, 1982). Elther of these mechanisms would produce a close correspondence between size at first reproduction and ize that prey outgrow predators 
as seen in PP. We do not know if life history differences between bluegill from PP and those from flehed populations are genetically based, or if they are phenotypic responses to differing ecological presaures.

The relationehip between predation arid ize at first reproduction would affect the variance in 120 of reproductive individuals in the population. If predation constraine minimum size at first reproduction to a relatively large size (a.g., Par Pond), the variance in 120 of reproductive individuals would be maller relative to aysteme where reproduction begins at emall slzes. High variance in body ize of reproductive males is characterietic of bluegill populatione where some males exhibit alternative reproductive behaviors (Gross, 1979; Dominey, 1980; Grose and Charnov 1980). Reproduct1ve males varled from about $80->200 \mathrm{~mm}$ TL in one population (Grose, 1982). Reproductive succese of males using alternative behaviors is dependent on their erequency in the population (Grose 1984). Therefore, if mortality rates of males that reproduce at small size increase because of increased predation, then the proportion of males maturing at small size would decrease (even though their individual reproductive success may be high). Thus, heavy predation should greatly decrease abundance of males using alternative reproductive behaviors at the adult stage (Gross, 1991). Large average body size of reproductive male bluegill in PP 
suggests that few if any males mature early and behave as cuckolders, or that those that do mature early are eliminated erom the population by predation. small variance in body size among reproductive males in PP 1s consistent with the hypothesis that predation may constrain the size at firat reproduction and preclude alternative reproductive behaviors of male bluegill in PP.

Community etructure. -- Predation can change community structure of competing prey by reducing populatione of dominant competitora thereby allowing competitively subordinate prey apecies to increase (Brooks and Dodilon, 1965 ; Wilbur, 1972 ; Palne, 1974 ; Morin, 1983). Small 120 classes of sunfish, Inpomin upp., have been shown to compete for resources while occupying vegetated refuge habitats (Werner et al., 1983; Mittlebach and Cheseon, 1987; Mittlebach, 1988). Blueg111 are usually dominant competitore in lakes, ponds, and reservoirs, greatly outnumbering other specles of sunfieh (Mittlebach, 1988). One might expect that low denelty of juvenile bluegili in PP, resulting from heavy predation, would allow other Lepomis species to increase. Sunfish other than bluegill comprised 27 and 68 respectively, of total numbers of sunfish in PP and Russell Reservolr, located on the border between south Carolina and Georgia (Clugston, 1973; Hogan, 1977; Germann and Bunch, 1990). Sunfish other than bluegill 
comprised 41 and $16 \%$, respectively, of total Lepomis blomass in PP and local reservolrs (average from Lake Thurmond, Lake secession, Lake Hartwell, and Lake Greenwood, range $=12$ 208). Total number of species of Laponil in systems compared above ranged from 4-6; however, there was no relationship between number of species and percent composition of non-blueg111 species. It appeare that heavy predation leade to increased numbers of individuals and blomase of other Lepomin epecies relative to those of blueg111.

Thermal effluent. -- Differences in bluegill growth and reproduction between PP and public reservoirs seem largely attributable to differences in abundance and size-structure of predators in the two reservolre. However, PP is a cooling reservoir for a nuclear reactor, and recelves thermal effluant. Could differences in bluegill growth and reproduction be due to the effect of thermal effluents?

several ines of evidence suggest that thermal effluent cannot account for differences in blueg1l1 growth. First, growth of Age I bluegill from a sample collected near the area of thermal inflow was no higher than growth in ambient areas of PP (thermal area: mean $=66.8 \mathrm{~mm} T L, S E=1.53, N=$ 47; compare to growth estimates from Table 1), and there was no difference in body condition factors between blueg 111 from thermally affected areas and other areas of PP (Paller 
and Saul, 1985). Second, thermal effluent in PP affects only one arm of the reservolr (surface temperatures near the input point of thermal effluent average $4-6^{\circ} \mathrm{C}$ higher than other areas of the reservolr; Wilde, 1985.), and it is unlikely that growth of bluegill is altered in unaffected areas of the reservolr. Third, some populations used for comparison were from reservolrs receiving thermal effluent, but growth in these populations was similar to that of populations in reservoirs not receiving thermal effluent (See references in Append $1 x$ ).

Changes in water temperature can cause false annull to form on otoliths of bluegill (Schramm, 1989). Collections of bluegill from PP were intentionally taken from the area unaffected by thermal effluent. In general, otclith annull were distinct and false annuli seldom formed in PP bluegill (Hales and Belk, in press). Mistakenly counting false annuli as true annuli (1.e., if age was overestimated), would decrease estimates of growth, making growth of bluegill in PP similar to other populations. Hence, the growth curve constructed for fish in PP is conservative. Reservolrs used for comparison are similar to PP in many respects. They have common topographic features, are located in similar cilmatic regions, and they include the same complement of dominant species (blueg111; black basses; crapple, Pomoxis spp.; and catflsh, Ictalurus spp.). It seems unlikely that other factors, besides differences in 
predator abundance and size, could account for observed differences in bluegill.

In summary, the pattern of growth and reproduction of bluegill in PP clearly differs from that of bluegill in typical southeastern reservoirs. Heavy predation, by the abundant largemouth bass population in PP, is the most plausible explanation for observed differences in bluegill between PP and other reservoirs, but other possible factors can not be entirely discounted. It appears that magnitude and direction of the effect of predators on bluegill growth and reproduction depends on the abundance and size-structure of the predator population.

\section{APPENDIX}

References for compiled growth curves of bluegill in the southeastern U.S. used to generate Figures 1, 2, and 3 are listed below. States in which reservoirs are located are designated in parentheses, and reservoirs receiving thermal effluent are designated by an " $\mathrm{H}$ ". APPLEGATE, R.L., J.W. MULLAN, AND D.I. MORAIS. 1967. Food and growth of six centrarchids from shoreline areas of Bull Shoals Reservoir. Proc. S.E. Assoc. Game and Fish Comm. $20: 469-482$. (AR)

BAF!WICK, D.H., AND W.E. LORENZEN. 1984, Growth responses of fish to changing environmental conditions in a south 
Carolina cooling reservoir. Env. Biol. Fish. 10:271279. (SC, H)

BEISSER, G.S. 1989. The fish populations and sport fishery of Allatoona reservoir, 1980-1987. Project F-36-10, Final Report, Georgia Dept. Nat. Res., Game and Fish Div., Atlanta, Georgia. (GA)

GERMANN, J.F., AND Z.E. BUNCH. 1990. A fishery survey of Richard B. Russell Reservoir 1984-1989:"the early years". Project F-26-17, Final Report, Georgia Dept. Nat. Res., Game and Fish Div, Atlanta, Georgia. (GA) HANCOCK, H.M. 1955. Age and growth of some of the principal fishes in Canton Reservoir, Oklahoma, 1951, with particular emphasis on the white crappie. Okla. Fish and Game Counc., Proj. Rep. Part 2. (OK) HOGUE, J.J., JR., AND R.V. KILAMBI. 1975. Age and growth of bluegill, Lepomis macrochirus Rafinesque, from Lake Fort Smith, Arkansas. Arkansas Acad. of Sci., Proc. $29: 43-46$. (AR)

JACKSON, S.W., Jr. 1966. Summary of fishery management activities on Lakes Eucha and Spavinaw, Oklahoma 19511964. Proc. S.E. Assoc. Game and Fish Comm. 19:315343. (OK)

KING, J.E. 1955. Growth rates of fishes of Lake Hiwassee, oklahoma, after two years of attempted population control. Proc. Okla. Acad. Sci. 34:53-56. (OK) 
LANE, C.E., Jr. 1954. Age and growth of bluegill in a new impoundment. J. Wildl. Manage. 18:358-365. (MO)

MONTGOMERY, A.B. 1956. Age and growth of the bluegill,

Lepomis $\mathrm{m}$. macrochirus Rafinesque, in the Niangua Arm of the Lake of the Ozarks. Unpubl. M.s. thesis, University of Missouri. (MO)

O'REAR, R.S. 1970. A growth study of redbreast, Lepomis auritus (Gunther), and bluegill, Lepomis macrochirus (Rafinesque), populations in a thermally influenced lake. Proc. S.E. Assoc. Game Fish Comm. 23:545-553. $(\mathrm{GA}, \mathrm{H})$

RAWSON, D.S. 1952. Mean depth and the fish production of large lakes. Ecology 33:513-521. (NC) RICHARDSON, F., AND H.M. RATLEDGE. 1961. Upper Catawba River Reservoirs and Lake Lure. N.C. Wildl. Res. Comm. Fed. Aid Proj. F5R and F6R Job Compl. Rep. 1:161-231. (NC)

SERNS, S.L., AND K. STRAWN. 1975. Age and growth of bluegill, Lepomis macrochirus, in two heated Texas reservoirs. Trans. Am. Fish. Soc. 104:506-512. (TX, H)

TATUM, B. 1961. Yadkin and Lower Catawba River reservoirs. N.C. Wildl. Res. Comm. Red. Aid Proj. F5R and F6R. Job Compl. Rep. 1:99-158. (NC) 
TIMMONS, T.J., AND R.D. ESTES. 1980. Age and growth of bluegills in Nickajack Reservoir, Tennessee. J. T inn. Acad. Sci. 55:137-138.

\section{ACKNOWLEDGMENTS}

We are indebted to many people for their help in collecting samples for this study. We thank D. Winkelman, J. Wallin, S. McAlpine, R. Fletcher, A. DeBiase, C. Tuckfield, M. Paller, and Y. Van Alstine. We thank D. Winkelman, G. Meffe, J. Congdon, R. Warren, and G. Helfman for reading drafts of the manuscript and providing helpful comments for its improvement. This research was supported by contract DEACO9-76SROO-819 from the U.S. Department of Energy to the Savannah River Ecology Laboratory, and was based on work performed in the Laboratory Graduate Participation Program by MCB under contract number DE-AC05-760R00033 between the U. S. Department of Energy and Oak Ridge Associated Universities.

\section{LITERATURE CITED}

ABRAHAMS, M.V., AND L.M. DILL. 1989. A determination of the energetic equivalence of the risk of predation. Ecology 70:999-1007.

AGER, L.M. 1988. Effects of an increased size limit for largemouth bass on fish populations in West Point 
Reservoir. Project F-33, Georgia Dept. Nat. Res., Game and Fish Div., Atlanta, Georgia.

BEISSER, G.S. 1989. The fish populations and sport fishery of Allatoona reservoir, 1980-1987. Project F-36-10, Final Report, Georgia Dept. Nat. Res., Game and Fish Div., Atlanta, Georgia.

BENNETT, D.H., AND R.W. MCFARLANE. 1983. The fishes of the Savannah River Plant: national environmental research park. SRO-NERP-12, U. S. Department of EnergY, Washington D.C.

BROOKS, J.L., AND S.I. DODSON. 1965. Predation, body size, and the composition of plankton. Science 150:28-35. CAMPANA, S.E. 1990. How reliable are growth backcalculations based on otoliths? Can. J. Fish. Aquat. Sci. $47: 2219-2227$.

CARLANDER, K.D. 1977. Handbook of Freshwater Fishery Biology, Volume 2. Iowa State University Press, Ames, Iowa.

CLUGSTON, J.P. 1973. The effects of heated effluents from a nuclear reactor on species diversity, abundance, reproduction, and movement of fish. Unpubl. Ph.D. diss., University of Georgia, Athens, Georgia. CROWL, T.A., AND A.P. COVICH. 1990. Predator-induced lifehistory shifts in a freshwater snail. Science 247:949951. 
DOMINEY, W.J. 1980. Female mimicry in male bluegill sunfish - a genetic polymorphism? Nature 284:546-548. EVANS, J.W. 1989. A survey of the largemouth bass fishery on Lake sinclair. Project F-33, Final Report, Georgia Dept. Nat. Res., Game and Fish Div., Atlanta, Georgia. FORSYTHE, T.D., AND W.B. WRENN. 1979. Predator-prey relationships among walleye and bluegill, p. 475-482. In: Predator-prey systems in Fisheries Management. $H$. Clepper (ed.). Sport Fishing Institute, Washington D.C.

GERMANN, J.F., AND Z.E. BUNCH. 1990. A fishery survey of Richard B. Russell Reservoir 1984-1989:"the early years". Project F-26-17, Final Report, Georgia Dept. Nat. Res., Game and Fish Div., Atlanta, Georgia. GIBBONS, J.W. , D.H. BENNETT, G.W. ESCH, AND T.C. HAZEN. 1978. Effects of thermal effluent on body condition of largemouth bass. Nature 274:470-471.

GIBBONS, J.W., J.T. HOOK, AND D.L. FORNEY. 1972. Winter responses of largemouth bass to heated effluent from a nuclear reactor. Prog. Fish-cult. 34:88-90.

GILBERT, R.J., AND J.E. HIGHTOWER. 1981. Assessment of tag losses and mortality of largemouth bass in an unfished reservoir. Project F-37-2, Final Report, Georgia Dept. Nat. Res., Game and Fish Div., Atlanta, Georgia. 
GILLIAM, J.F., AND D.F. FRASER. 1987. Habitat selection under predation hazard: test of a model with foraging minnows. Ecology $68: 1856-1862$.

GOTCEITAS, V., AND P. COLGAN. 1990. The effects of prey availability and predation risk on habitat selection by juvenile bluegill sunfish. Copeia 1990:409-417.

GRoss, M.R. 1979. Cuckoldry in sunfishes (Lepomis:

Centrarchidae) . Can. J. Z0,0l. 57:1507-1509.

-n-. 1982. Sneakers, sateliltes and parentals:

polymorphic mating strategies in North American

sunfishes. Z. Tierpsychol. 60:1-26.

---. 1984. Sunfish, salmon, and the evolution of

alternative reproductive strategies and tactics in

fishes, p. 55-75. In: Fish Reproduction: strategies

and Tactics. R.J. Wootton, and G.W. Potts (eds.).

Academic Press, London.

---. 1991. Salmon breeding behavior and life history evolution in changing environments. Ecology 72:11801186.

GROSS, M.R., AND E.L. CHARNOV. 1980. Alternative male life histories in bluegill sunfish. Proc. Nat. Acad. Sci., U.S.A. $77: 6937-6940$.

HALES, L.S., JR., AND M.C. BELK. 1992. Validation of otolith annuli of bluegill in a southeastern reservoir. Trans. Am. Fish. Soc., in press. 
HAMBRIGHT, K.D. 1991. Experimental analysis of prey selection by largemouth bass: role of predator mouth width and prey body depth. Trans. Am. Fish. Soc. $120: 500-508$.

HOGAN, D.C. 1977. Distribution and relative abundance of prey fish in a reservoir recelving a thermal effluent. Unpubl. M.s. thesis, University of Georgia, Athens, Georgia.

JENKINS, R.M. 1975. Black bass crops and species associations in reservoirs, p. 114-124. In: Black Bass Biology and Management. R.H. stroud, and H. Clepper (eds.). Sport Fisheries Institute, Washington D.C. LAW, R. 1979. Optimal life histories under age-specific predation. Am. Nat. 114:399-417.

LAWRENCE, J.M. 1957. Estimated sizes of various forage fishes largemouth bass can swallow. Proc. S.E. Ass. Game and Fish Comm. 11:220-226.

MARTIN, C.R., AND T.B. HESS. 1984. Analyils of the fish population and $f$ ishery of Lake Oconee. Project F-26-5, Final Report, Georgia Dept. Nat. Res., Game and Fish Div., Atlanta, Georgia.

MAGNHAGEN, C. 1990. Reproduction under predation risk in the sand goby, Pomatoschistus minutus, and the black goby, Goblus niger: the effect of age and longevity. Behav. Ecol. Sociobiol. 26:331-335. 
MICHOD, R.E. 1979. Evolution of life histories in response to age-specific mortality factors. Am. Nat. 113:531550

MITTLEBACH, G.G. 1988. Competition among refuging sunfishes and effects of fish density on littoral zone invertebrates. Ecology 69:614-623.

MITTLEBACH, G.G., AND P.L. CHESSON. 1987. predation risk: indirect effects on 11sh populations, p. 315-332. In: Predation: Direct and Indirect Impacts on Aquatic Communities. W.C. Kerfoot, and A. Sih (eds.). University Press of New England, Hanover, New Hampshire.

MORIN, P.J. 1983. Predation, competition, and the composition of larval anuran guilds. Ecol. Mon. $53: 119-138$.

NASH, V.S., R.L. SELF, AND R.M. STROUD. 1989. Flsherles investigations in lakes and streams, District IV. Study Completion Report F-11, S.C. Wildlife and Marine Res. Dept., Div. Wildilfe and Freshwater Fisheries, Columbia, south carolina.

PAINE, R.T. 1974. Intertidal community structure. Experimental studies on the relationship between a dominant competitor and its principal predator. Oecologia 15:93-120.

PALLER, M.H., AND B.M. SAUL. 1985. Final report on the adult $f$ ish and icthyoplankton of Par Pond and Pond B: 
January 1984 - June 1985. Report DPST-85-791, E. I. du Pont de Nemours and Company, Savannah River Laboratory, Aiken, South Carolina.

POLICANSKY, D. 1983. Size, age and demography of metamorphosis and sexual maturation in fishes. Am. 2001. $23: 57-63$.

REZNICK, D.N., AND J.A. ENDLER. 1982. The impact of predation on life history evolution in Trinidadian guppies (Poecilia reticulata). Evolution 36:160-177. RICKER, W.E. 1975. Computation and interpretation of blological statistics of fish populations. Bulletin $\$ 191$ Fish. Res. Bd. Canada.

SCHRAMM, H.L., Jr. 1989. Formation of annull in otolithe of blueg111s. Trans. Am. Fish. Soc. 118:546-555.

SIH, A. 1987. Predators and prey lifestyles: an evolutionary and ecological overview, p. 203-224. In: Predation: Direct and Indirect Impacts on Aquatic Communities. W.C. Kerfoot and A. Sin (eds.). University Press of New England, Hanover, New Hampshire.

SIH, A., P. CROWLEY, M. MCPEEK, J. PETRANKA, AND K. STROHMEIER. 1985. Predation, competition, and prey communities: a review of field experiments. Ann. Rev. Ecol. Syst. 16:269-311. 
SKELLY, D.K. 1992. Fleld evidence for a cost of behavioral antipredator response in a larval amphibian. Ecology $73: 704-708$.

SKELLY, D.K., AND E.E. WERNER. 1990. Behavioral and 11fehistorical responses of larval american toads to an odonate predator. Ecology 71:2313-2322.

SNYDER, D.E. 1983. Fich egge and larvae, p. 165-197. In: Fisheries Techniques. L.A. Nielson and D.L. Johnson (eds.). American Fisheries soclety, Bethesda, Maryland.

STEIN, R.A., AND J.J. MAGNUSON. 1976. Behavioral response of a crayfish to a fish predator. Ecology 58:571-581. SWINGLE, H.S. 1951. Relationahipe and dynamice of balanced and unbalanced fish populations. Bull. Ala. Agric. Exp. Stn. 274:1-62.

TRIPPEL, E.A., AND H.H. HARVEY, 1991. Comparison of methode used to estimate age and length of fishes at sexual maturity using populations of white sucker (catontomue sommersoni). Can. J. Fish. Aquat. Sc1. $48: 1446-1459$.

WEAVER, O.R. 1981. Georgla reservolr floh population statistics. Profect F-25-8, Final Report, Georgia Dept. Nat. Res., Game and Fiah Div., Atlanta, Georgia. WERNER, E.E., AND J.F. GILLIAM. 1984. The ontogenetic niche and species interactions in size-structured populations. Ann. Rev. Ecol. Syst. 15:393-425. 
WERNER, E.E., J.F. GILLIAM, D.J. HALL, AND G.G. MITTELBACH. 1983. An experimental test of the effects of predation risk on habltat use in fish. Ecology $64: 1540-1548$. WERNER, E.E., AND D.J. HALL. 1988, Ont genetic habitat shifte in bluegill: the foraging rate-predation riok trade-off. Ecology $69: 1352-1366$.

WHITE, G. C., D. R. ANDERSON, K. P. BURNHAM, AND D. L. OTIS. 1982. Capture-recapture and removal methods for sampling closed populations. LA-8787-NERP, UC-11, U. 8. Department of Energy, Washington, D.C. WILBUR, H.M. 1972. Competition, predation, and the structure of the ambyntoma-Bana aylyatica community. Ecology 53:3-21.

-... 1987. Regulation of structure in complex syateme: experimental temporary pond communities. Ecology $68: 1437-1452$.

WILDE, E.W. 1985. Compliance of the Savannah River Plant p-reactor cooling yatem with environmental regulations. Report DP-1708, E. I. du Pont de Nemours and Co., Savannah River Laboratory, Alken, south Carolina. 
Table 1. Length at capture, and back-calculated total lengthe (in mm) of Inpomie macrochirue from Par Pond.

\section{lenath at capture mean back-calculated length at annulue}

\begin{tabular}{|c|c|c|c|c|c|c|c|c|c|c|c|c|}
\hline 192 & $\mathbf{N}$ & man & renge & 1 & 2 & 3 & 1 & 5 & 6 & 1 & 8 & 9 \\
\hline 1 & 147 & 66 & $37-114$ & 60 & & & & & & & & \\
\hline 2 & 95 & 123 & $88-188$ & 69 & 115 & & & & & & & \\
\hline 3 & 27 & 188 & $132-271$ & 84 & 139 & 179 & & & & & & \\
\hline 4 & 60 & 248 & $157-278$ & 92 & 159 & 215 & 240 & & & & & \\
\hline 5 & 26 & 257 & $225-275$ & 85 & 152 & 212 & 239 & 252 & & & & \\
\hline 6 & 6 & 259 & $246-275$ & 82 & 147 & 204 & 236 & 250 & 256 & & & \\
\hline 7 & 9 & 263 & $252-267$ & 88 & 147 & 201 & 234 & 248 & 255 & 259 & & \\
\hline 8 & 3 & 264 & $260-269$ & 82 & 144 & 209 & 238 & 248 & 254 & 257 & 260 & \\
\hline 2 & 1 & 260 & - & 64 & 124 & 185 & 222 & 232 & 245 & 252 & 260 & 260 \\
\hline
\end{tabular}

Total 374 Qverall mane $\begin{array}{lllllllll}72 & 136 & 205 & 239 & 251 & 254 & 258 & 260 & 260\end{array}$ 
Figure 1. Back-calculated growth curve of Lepomis macrochirue from Par Pond. Enclosed area reprewents range of bluegill growth curves from other southeastern U.5. reservolrs, including those recelving thermal effluent (Appendix). Shaded bars represent estimated size interval where 50 t of bluegill are reproductively active and age range over which they mature. 


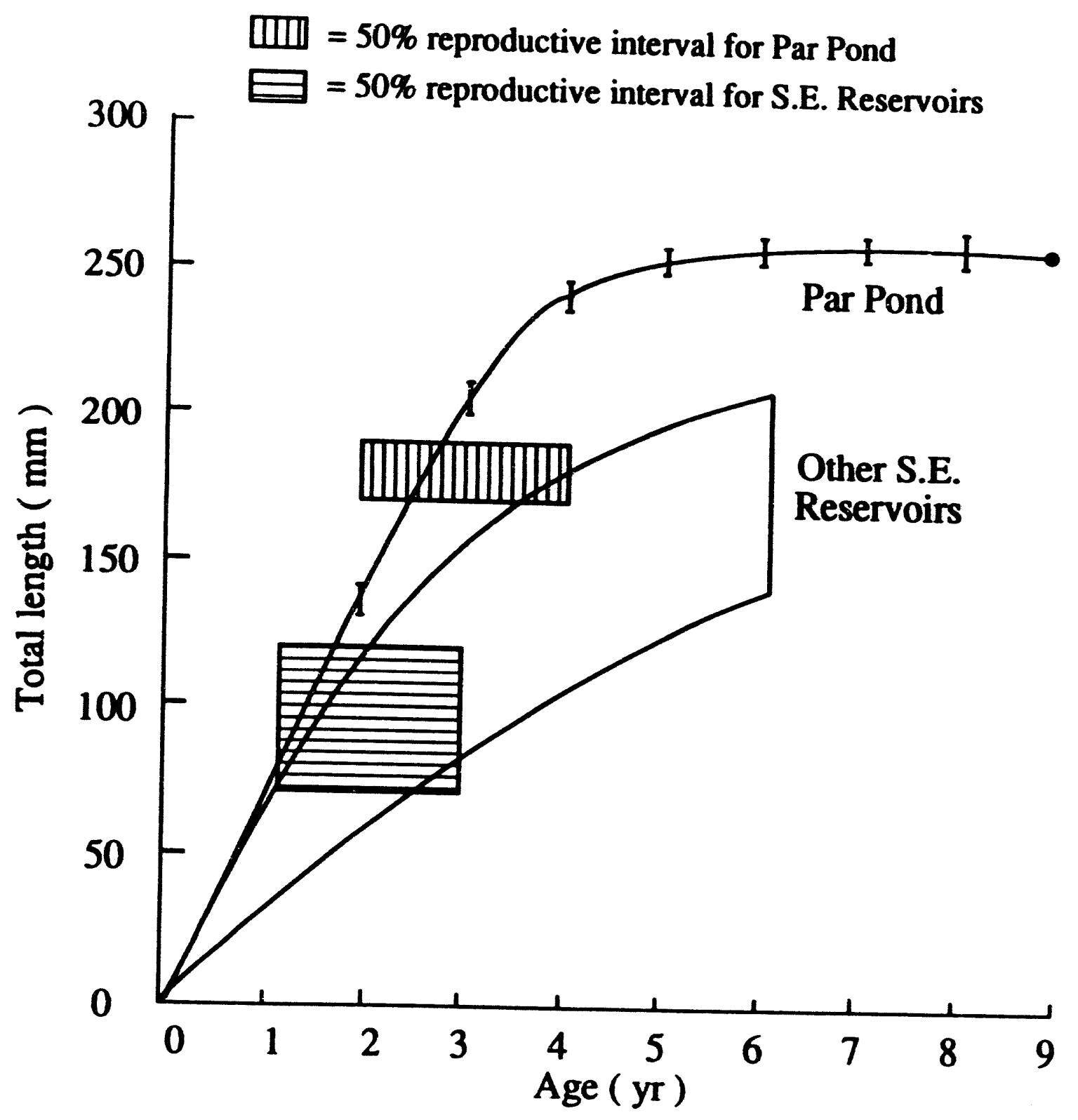


Figure 2. Plot of the annual growth increment of bluegill in Par Pond (solid line) and the average annual growth increment from the 30 growth curves from public reservoirs in the southeastern U.S. (dashed line). Vertical bars represent $95 \%$ confidence intervals about the mean. 


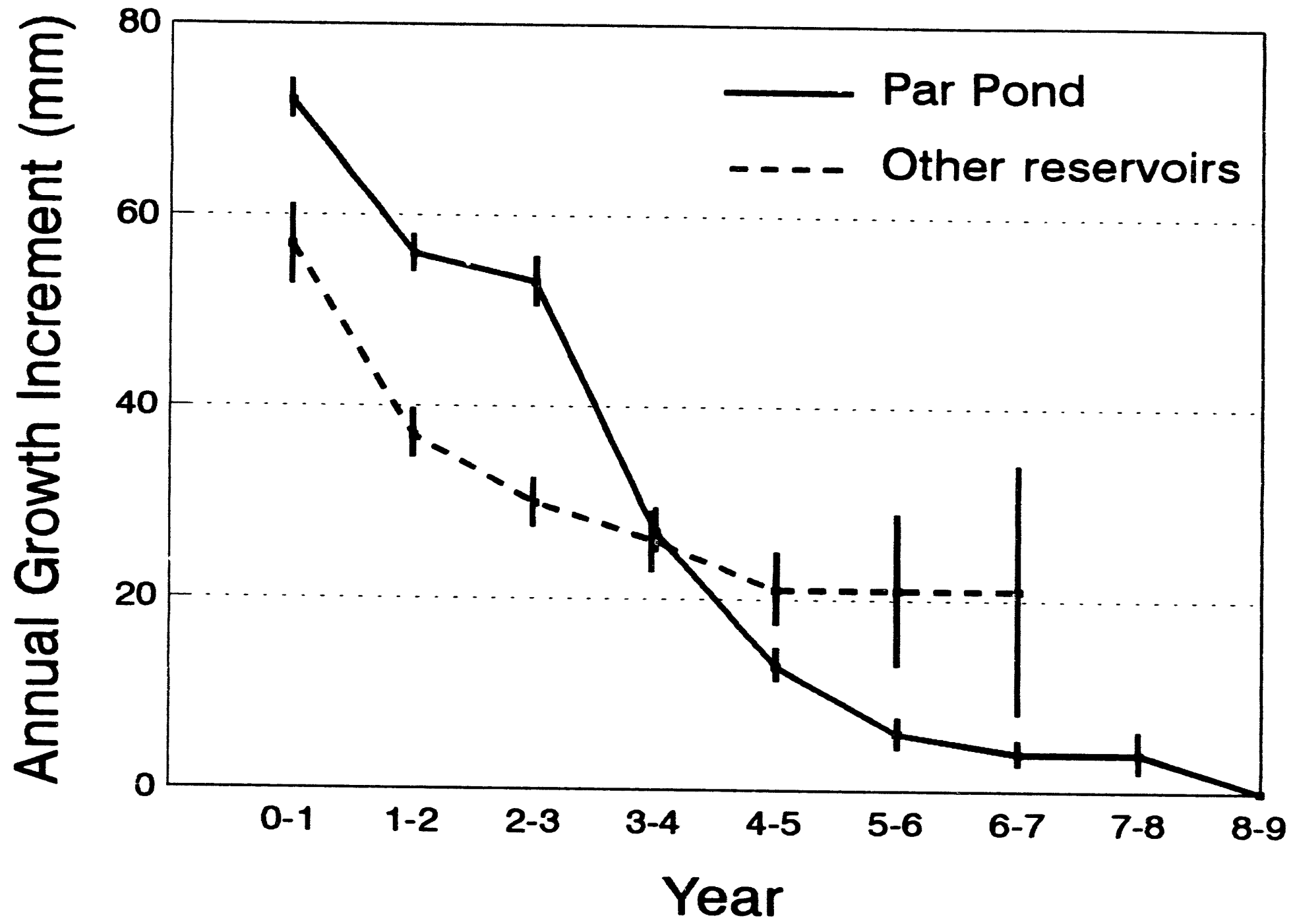


Figure 3. Length-frequency distribution of reproductively active male (open bars) alid female (solid bars) bluegill from Par Pond. 


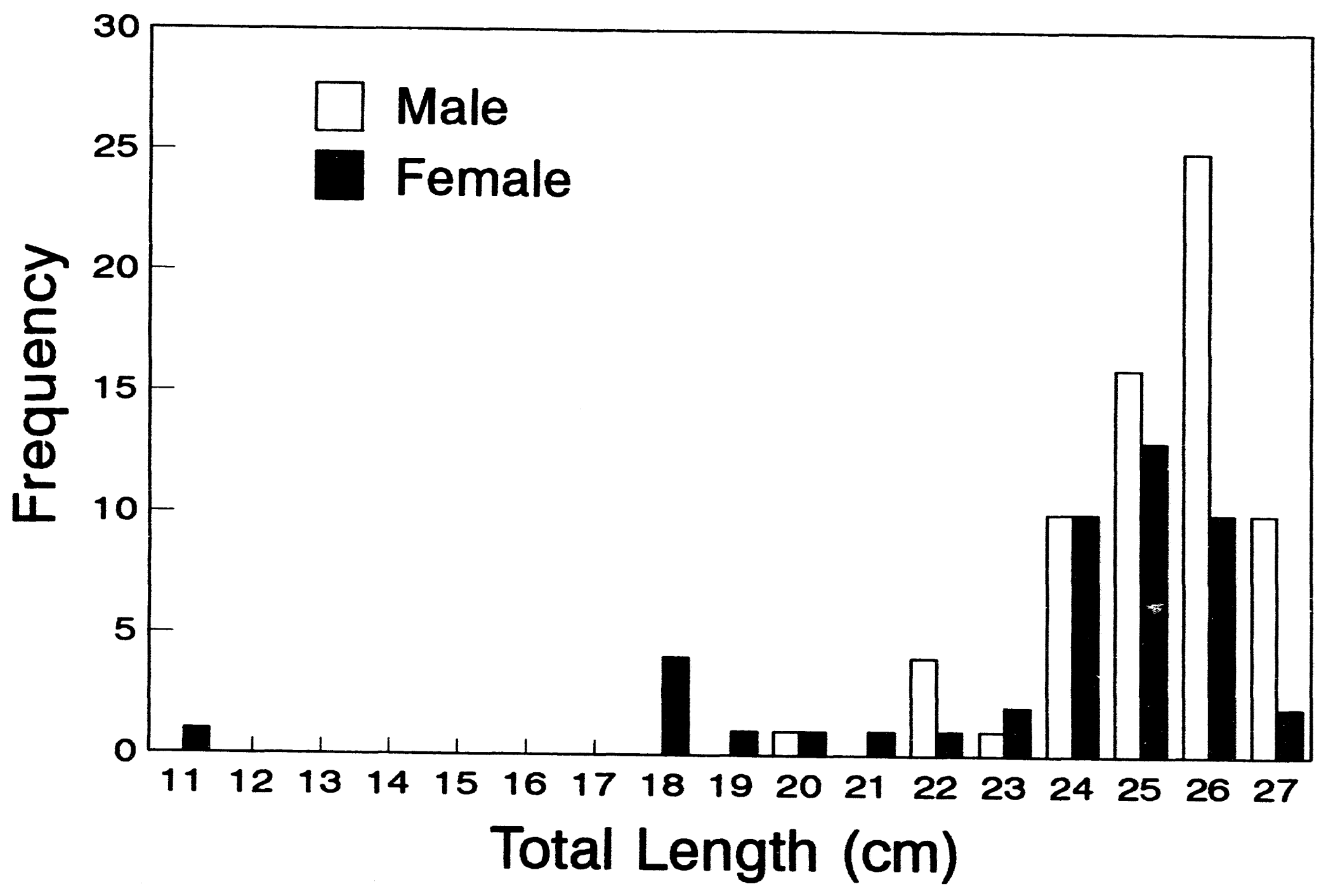


Figure 4. Model of the balance between positive and negative effects of predators on prey growth rates as influenced by predator abundance and size. When predators are at low densities, nonlethal, behavioral effects of predators on prey are the primary influence on prey growth rates, but when predator densities are high, lethal effects of predators on prey populations are the primary influence on growth rates. See text for further discussion. 


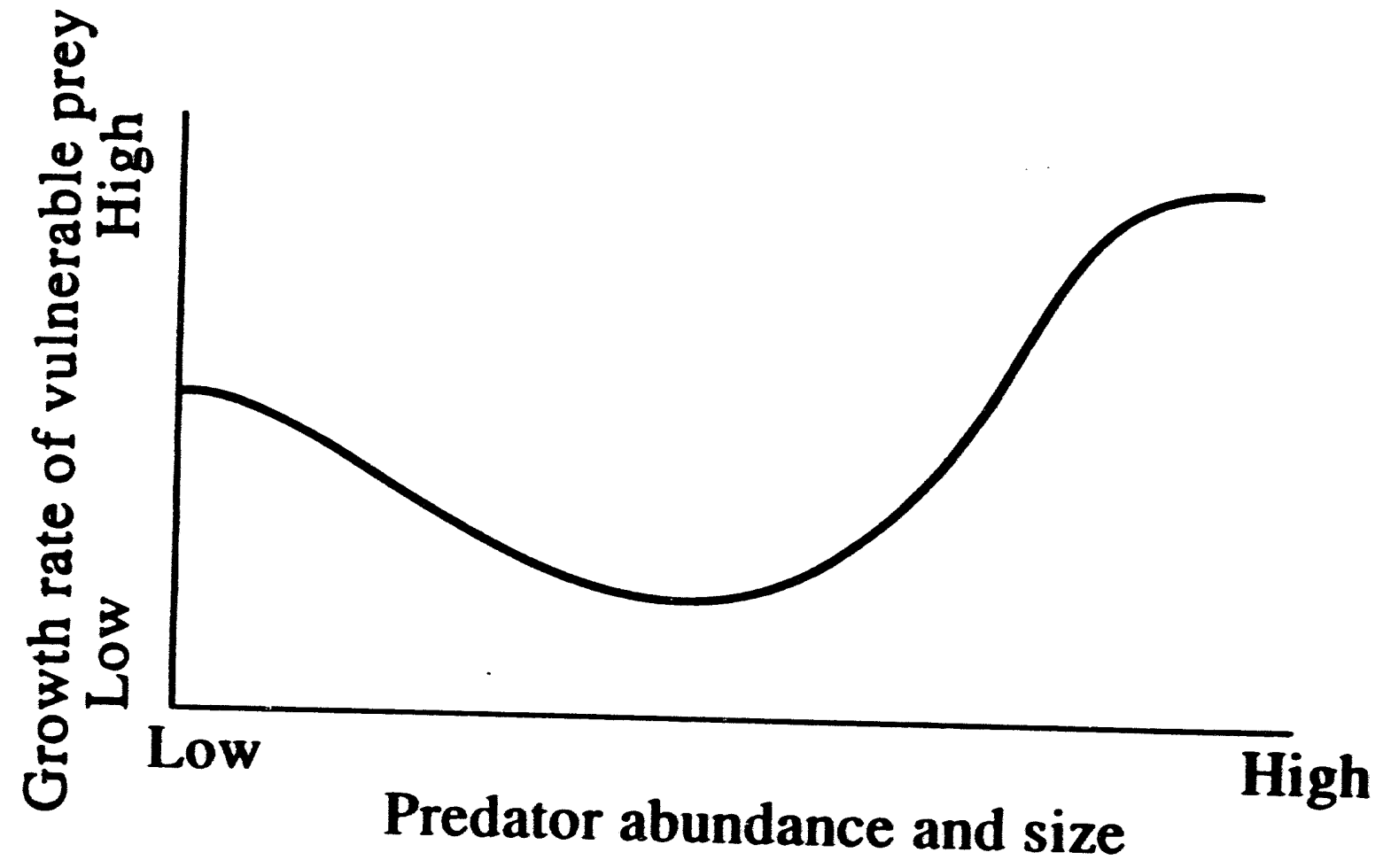


Competition among juvenile sunfishes (Lepomis spp.)

under heavy predation'

'Belk, M.C. Submitted to Ecology, 5/8/92. 
Abstract. To determine what effect an abundant predator population would have on the potential for competition among refuging sunfish, intraspecific competition among bluegill sunfish (Lepomis macrochirus) and interspecific competition between bluegills and two other species of sunfish (spotted sunfish, L. punctatue, and warmouth, L. gulosue), was evaluated experimentally in a large reservoir with an abundant population of large predators (largemouth bass, Micropterus salmoides). Growth rates of bluegills were unaffected by presence of other Lepomis species, but growth rates decreased with increasing bluegill density. However, growth rates of bluegills at densities corresponding to those found in the reservoir were high, and competition appeared to be unimportant at these densities. Growth rates of bluegilis in vegetated refuge areas were about $1.5 \mathrm{x}$ higher than growth in open, risky habitats. Percent lipid content of bluegills generally was unaffected by treatments. In Par Pond, fuvenile bluegills were found at relatively low densities and have high growth rates in refuge environments, indicating a strong lethal effect of predators on bluegill population dynamics. Combined results of this study and previous studies on bluegills suggest that at low to moderate predator densities nonlethal effects are important, whereas at high predator densities lethal effects of predators are most important in determining dynamics of bluegill populations. 
Key Words: competition, predation, growth, lipid levels, refuging prey, lethal effects, nonlethal effects, bluegill, Lepomis macrochirus.

10-Year Index Entries: competition under heavy predation, lethal and nonlethal predator effects, competition among refuging prey, growth-rate/predation-risk tradeofe.

\section{INTRODUCTION}

competition and predation are often considered dominant forces in animal population regulation (Hairston et al. 1960, Menge and sutherland 1987, sih et al. 1985). Traditionally, these forces have been considered separately; most debate has centered on whether competition or predation was the dominant biotic force structuring communities (sih et al. 1985). More recently, ecologists have realized the interactive nature of predation and competition, revealing a varlety of complex effects among competitors and between predators and prey (Mittlebach 1986, Miller and Kerfeot 1987, Kotler and Holt 1989). Predation can influence prey population dynamics in two distinct ways (Kotler and Holt 1989): 1) directly via lethal effects, by altering mortality rates and density (Sih 1987, "trophic-link effect" sensu Miller and Kerfoot 1987), and 2) by nonlethal effects, such as altering prey behavior (e.g., habitat cholce, diet, and 
movement patterns; "behavioral indirect effect" sensu Miller and Kerfoot 1987 ).

Bluegill suntish (Lepomin macrochirus), and other Lepomie species, are abundant in many ereshwater systems in the U.S., where they are preyed upon by many aquatic vertebrates. Previous work has shown that lethal effects of predation on bluegill populations tend to decrease the potential for competition among fuvenile bluegilis due to reductions in density (Swingle 1951, Foreythe and Wrenn 1979), whereas, nonlethal effects can increase the potential for competition among bluegille in vulnerable size-classes (Werner et al. 1983, Mittlebach 1988, Werner and Hal1 1988). It is not clear what characteristics of predator populations might favor predominance of lethal or nonlethal effects (Mittlebach and Cheseon 1987).

This paper is a report of experiments on the importance of Intraspecific competition among blueg111s and interspecific competition between bluegills and two other species of sunfish, spotted sunfish (L. punctatus) and warmouth (L. guloeus), in a large reservoir with an abundant predator population, mainly composed of largemouth bass (Micropterus salmoldes). In contrast to previous studies on the effects of predators on bluegllls, largemouth bass in this reservoir are very abundant and large. Other factors that could influence competitive interactions among sunfish also may vary between the reservoir in this study and 
previously studied systems; however, differences in the abundance of predators appeared to be the most plausible causal difference (Belk and Hales unpubl. ms.). My primary goal was to determine if the potential for competition was decreased due to high levels of predation, or if nonlethal effects of predators caused an increase in competition. Because energy can be used for growth or stored in the form of IIplds, both growth and Iipld content were used to evaluate the effect of Increased density of blueg111 and presence of other potential competitors.

\section{METHODS}

\section{study iten}

The study was conducted in Par Pond, a 1069-ha nuclear reactor cooling reservoir located on the savannah River site near Alken, south Carolina. The fish fauna of Par Pond $1 \mathrm{~s}$ dominated by large populations of largemouth bass, bluegill, and black crappie (Pomoxis ntaromaculatue). Other common species Include chain plckerel (Esox nfoer), warmouth, spotted sunfish, dollar sunfish (L. marainatus), redbreast sunfish (L. auritur), mosquitofish (Gambusta holbrooki), blueback herring (Alosa aestyalie), and brook silversides (Labldenthen Licculue, Bennett and MoFarlane 1983). Par Pond has not been open to public elshing since its construction in 1958, and largemouth bass there are about four times more abundant and 25 larger than bass in similar 
reservolrs that are fished (mean total length in Par Pond = $420 \mathrm{~mm}$; Gibbons and Bennett 1971, Belk and Hales unpublished ms.). Because of the abundance of natural predators, Par Pond provides an opportunity to test predictions about the effects of high levels of predation on prey ecology.

\section{Experiment 1}

The objective of Experiment 1 was to evaluate the potential for intraspecific competition in bluegilis and interspecific competition between bluegilis and the two next-most-common Lepomis species in Par Pond (spotted sunfish and warmouth). Densities of bluagilis, epotted sunfishes, and warmouthe were manipulated in enclosures located in the littoral zone of Par Pond, and differences in growth and lipid content of flsh were ueed to determine competitive effects. Enclosures measured $1.6 \mathrm{~m}$ on a side (about $2.5 \mathrm{~m}^{2}$ surface area) and were composed of frames made of PVC pipe $(3.2 \mathrm{~cm}$ diameter) covered with $0.6 \mathrm{~cm}$ mesh aquaculture netting. Enclosures were anchored firmly to the substrate by driving $3 \mathrm{~m}$ lengths of electrical conduit into the substrate at each corner and securing the enclosure to the conduit with hose clamps. Each enclosure was checked for a firm fit to the substrate by sorkeling around the bottom; gaps were plugged with sandbags. Tops of enclosures were covered with $1.9 \mathrm{~cm}$ mesh flexible netting to prevent predation by large wading birds, otters, or alligators. 
Enclosures were located in homogeneous stands of eelgrass (Yaldienerta americana) in water about $1-1.5 \mathrm{~m}$ deep. Enclosures were intensively electroshocked using a backpack electroshocker to remove fish that were inadvertently captured when enclosures were inetalled.

Two treatments, bluegill density (four levels, 3, 6, 9, and 12 per enclosure) and presence or absence of spotted sunfish and warmouth (four individuals of each species), were crosed ylelding 8 treatment combinations. Densities of bluegills were selected to represent the range of densities observed among different bluegill populations as follows. Denelties of juvenile bluegills in Par Pond are relatively low and corresponded to the loweet density treatment (3/enclosure; Belk and Hales unpublished ms.). Density of fuvenile blueg111s reported in previous studies examining competition among refuging sunfish corresponded to intermediate density levels (6-9/cnclosure; Mittlebach 1988, Werner and Hall 1988). The highest density treatment (12/unclosure) corresponded to densities of juvenile bluegills in overcrowded, stunted populations (Swingle 1951). Treatments were replicated 5 times, and enclosures were arranged according to a randomized block design with 5 blocks of 8 enclosures being located along different sections of shoreline.

Bluegills, spotted sunfishes, and warmouths between 70 and $105 \mathrm{~mm}$ total length (corresponding to Age I bluegills; 
Belk and Hales unpublished ms.) were electroshocked and trapped from areas other than those surrounding the enclosures. Total length (in $\mathrm{mm}$ ) was recorded and individuals were arbitrarily assigned to enclosures. stocking was completed on 31 August 1990, and enclosures were monitored daily for the first two weeks and every 2-4 days thereafter. All dead fish observed in enclosures were removed, measured, and recorded, and for the first week were replaced with new individuals. During the third week of November 1990, fish were removed from enclosures using a large dipnet built to fit snugly inside the enclosure. Each enclosure was sampled until no fish were captured in three successive trials.

Total length $(\mathrm{mm})$ and mass (nearest $0.01 \mathrm{~g}$ ) were recorded for each fish. Mean gain in length was calculated as mean length of $f$ ish in each enclosure at the end of the experiment minus mean length of $\mathrm{fish}$ in each enclosure at the beginning. One entire replicate was inadvertently lost, so the analysis was based on only four replicates. of the original 240 bluegills placed in enclosures for Experiment 1 (excluding the lost replicate), 219 (91.1\%) were recovered at the end of the experiment. A total of 22 extra bluegills (mean $=0.69 /$ enclosure, range $=0-4)$ were retrieved from all enclosures. Fish were considered extra if they were smaller than fish added to the enclosure at the beginning of the experiment, or if they were considerably larger than 
expected given the average growth rate in the enclosure. Survivorship of spotted sunfishes was $81.3 \%(52 / 64)$, and survivorship of warmouths was $64.18(41 / 64)$. There were an average of 0.9 (range $=0-3$ ) extra spotted sunfishes or warmouths per enclosure (determined by same criteria used for bluegills). A total of 13 fish of other species were recovered from enclosures; all were young-of-year, and probably entered enclosures as larvae. Bluegills that died during the experiment and extra bluegills were excluded from calculations. Growth of bluegills in enclosures was compared by analysis of covariance (ANCOVA) using starting mean length and standard deviation of starting length as covariates. Variances of treatment groups were checked for equality by regressing means on variances. $\log _{10}$ transform of growth data proved most effective in stabilizing the variance, so transformed values were used in the analysis. Otoliths (sagittae) were removed for growth comparison with fish outside enclosures, and fish were kept frozen until lipid extractions could be done.

At the same time fish were removed from enclosures, 24 bluegills from outside the enclosures were collected by electroshocking to see how growth in the reservoix compared to growth in the lowest density treatment. Growth of bluegills outside the enclosures and those in the lowest density treatment during the time of the experiment was determined by the use of daily growth increments evident on 
otoliths. Otoliths were cross sectioned and daily rings counted ( $800 \mathrm{x}$ magnification) according to methods in Haake et al. (1981) and Schultz and Taylor (1987). The size of fish at the beginning of the experiment was determined by counting 75 daily rings back from the outer margin (corresponding to the duration of the experiment) and calculating size using a modified Fraser-Lee method (Campana 1990). Gain in length (calculated as current length minus beginning length) was compared between the two samples with a t-test (a plot of means versus variances indicated roughly equal variances among treatment groups, and the variable was approximately normally distributed).

Comparisons of growth estimates derived from measurements of daily growth increments on otoliths between populations experiencing different environmental conditions may not be valid (Campana 1990). However, within populations where individuals are growing rapidly daily increments on otoliths are probably reliable indicators of growth. To validate the reliability of growth estimates derived from daily otolith increments, I compared growth estimates for bluegills in the lowest density treatments, derived from analysis of otoliths, to growth estimates derived from before and after measurements.

The lowest treatment density ( 3 bluegill/enclosure) corresponded to ambient densities of bluegills in Par Pond. A lower density treatment (i.e., representing densities 
lower than those found in Par Pond) could not be included in the experiment due to logistic constraints on the size of enclosures, and the need for at least 3 individuals in each enclosure to allow for possible mortalities. The possibility that bluegill would grow faster at densities lower than those found in Par Pond was evaluated indirectly as follows. Growth rates of Age I bluegills in Par Pond are extremely high compared to other bluegill populations (Belk and Hales unpublished ms.). Thus, if growth in the lowest density treatment (corresponding to actual densities in Par Pond) was equivalent to growth outside enclosures that would suggest that bluegill in the low density treatment were growing at a near-maximum rate. Hence, further decreases in density would be unlikely to lead to increased growth rates. Accordingly, there would be little evidence for intraspecific competition affecting bluegill growth rates in this reservoir.

\section{Experiment $\underline{2}$}

The objective of Experiment 2 was to determine if growth rates or lipid content of juvenile bluegills differed between open, risky habitats and vegetated refuge habitats. Enclosures similar to those used in Experiment 1 were located in open areas and stocked with bluegills. Treatments were two densities of bluegills ( 3 and 12 /enclosure) in open or vegetated habitats. A full 
factorial design was used, and treatments were replicated four times. Enclosures located in vegetated areas were the same enclosures used for Experiment 1. Both experiments (1 and 2) were started and ended at the same time, and growth was calculated in the same way.

One replicate in the open water area was inadvertently lost, so the analysis includes three treatment replicates in open water habitats and four treatment replicates in vegetated habitat. of 105 bluegills added at the beginning, 95 were recovered at the end of the experiment (90.4\%). Also, three extra bluegills (as defined above) were retrieved. Variances of the growth variable were approximately equal (as determined by a plot of means versus variances) among treatment groups, so untransformed data were used in the analysis. Treatment differences were analyzed with analysis of covariance (ANCOVA) using mean beginning length as the covariate.

To determine differences in resources available in the two habitats, zooplankton and benthic macroinvertebrates were sampled in both habitats in early september. Zooplankton were sampled using a 3.31 Van Dorn bottle in three habitats; shallow vegetated habitats, shallow open habitats (both <3 $\mathrm{m}$ water depth), and deeper, open water habitats (samples taken at 1,3 , and $5 \mathrm{~m}$ depths). Benthic macroinvertebrates were sampled using a vacuum sampler (Brown et al. 1987) in shallow, vegetated and open habitats. 
A plexiglass tube, $19 \mathrm{~cm}$ diameter $\left(0.028 \mathrm{~m}^{2}\right.$ area), was placed firmly against the substrate, and the area inside was sampled systematically with the suction hose for $15 \mathrm{sec}$. Zooplankton and macroinvertebrates were preserved in $10 \%$ formalin/sucrose solution, and later stained (Rose Bengal stain) to aid in counting. All sampless were sieved (500-um mesh screen for macroinvertebrates; 8,0-um mesh screen for zooplankton) and counted at $25 \mathrm{x}$ (zooplankton) or $12 \mathrm{X}$ (macroinvertebrates).

Mortality rate was quantified in both habitats by tethering juvenile bluegills (71-109 $\mathrm{mm} \mathrm{TL})$ in both vegetated areas and nearby open areas and observing disappearance rates. Equal numbers and sizes of bluegills were individually attached to small floats with light monofilament fishing line and placed in both habitats. Time of placement and time of disappearance were noted for each fish. A total of 14 fish were tested in each habitat. Trials were run on two different occasions, with seven fish in each habitat per occasion. Tethered fish were placed a minimum of $20 \mathrm{~m}$ apart to reduce the probability of nonindependence between samples (Further spacing did not allow one observer to effectively monitor all fish at one time.). Mortality rates were compared using nonparametric test statistics available in the SAS procedure LIFETEST (SAS 1985) . 


\section{Lipids}

Bluegills from both experiments were dried for 3 days at $60^{\circ} \mathrm{C}$ then ground with a mortar and pestle. Non-polar lipids were extracted with ethyl ether in a soxhlet apparatus (Christie 1982). Samples were oven-dried for 24 hours then placed in a dessicator box for 24 hours before they were weighed. Mass was measured on a digital balance inside the dessicator. Lipid content (non-polar) was calculated as dry mass of the sample before extraction minus dry mass of the sample after extraction. Percent lipid was calculated as dry mass of lipid content divided by dry mass of the total fish multiplied by 100 . Data were tested for equality of variances among treatment groups, and a $L O G_{10}$ transform was used to stabilize the variances. Differences among groups were determined by analysis of variance (ANOVA) for Experiment 1, and analysis of covariance (ANCOVA), using mean beginning length as a covariate, for Experiment 2. All statistical tests were performed using the SAS procedure GLM (SAS 1985).

\section{RESULTS}

\section{Experiment 1}

Presence of spotted sunfishes and warmouths had no effect on bluegill growth $\left(F_{1,19}=0.09, P=0.76\right.$; Table 1$)$. However, increased density of bluegills significantly decreased growth rates $\left(F_{3,19}=16.08, P=0.0001 ;\right.$ Fig. 1a). 
Interaction between treatments was not significant $\left(F_{3,19}=0.35, P=0.79\right)$. The covariate, starting mean length, explained a significant amount of variation $\left(F_{1,19}=9.72\right.$, $\mathrm{P}=0.005$ ), but the standard deviation of starting length did not $\left(F_{1,19}=0.11, P=0.74\right)$.

Density of bluegills had no significant effect on percent lipid content $\left(F_{3,21}=0.23, P=0.87 ; F i g .1 \mathrm{~b}\right)$. Presence of other species also did not significantly affect percent lipid content $\left(F_{1,21}=2.61, \mathrm{P}=0.12\right.$; Table 1$)$. Interaction between treatments was not significant $\left(F_{3,21}=1.21, P=0.33\right)$. Growth of bluegills in the lowest density treatment $(N=23$ fish, $\bar{x}=13.4 \mathrm{~mm}, S E=0.67)$ was no different than growth of bluegills outside the enclosures ( $N=24$ fish, $\bar{x}=12.7 \mathrm{~mm}, S E=0.81$ ) as calculated using counts of daily growth rings on otoliths $\left(t_{45}=-0.64, \underline{P}=0.53\right)$. Growth estimates for bluegills in the lowest density treatments derived from analysis of otoliths $(\bar{x}=13.4 \mathrm{~mm}, N=23$ fish, $S E=0.67$ ) were comparable to growth estimates derived from before and after measurements $(\bar{x}=13.9 \mathrm{~mm}, N=8$ enclosures, $S E=0.53)$.

\section{Experiment 2}

Bluegills in vegetated habitats grew significantly faster than those in open habitats $\left(F_{1,8}=6.98, P=0.029\right.$; Table 2), and increased density of bluegills significantly 
decreased growth rates in both habitats (mean growth, low density $=11.00 \mathrm{~mm}, \mathrm{SE}=0.62$; mean growth, high density $=6.66$ $\left.\mathrm{mm}, \mathrm{SE}=0.62 ; \mathrm{F}_{1,8}=23.34, \mathrm{P}=0.001\right)$. Interaction between treatments was not significant $\left(F_{1,8}=2.02, P=0.19\right)$. The covariate, mean beginning length, explained a significant amount of variation $\left(F_{1,8}=7.37, P=0.03\right)$. Lipid levels did not vary significantly with treatments (habitat, $F_{1,10}=0.48$, $\mathrm{P}=0.51$; Table 2; density, $\mathrm{F}_{1,10}=0.30, \mathrm{P}=0.59$ ).

zooplankton in vegetated habitats in september were over six times as abundant as in open areas (vegetated = $267 / 1, N=2$, range $202-332 / 1$; shallow open $=41 / 1, N=2$, range $22-59 / 1$; deep open $=47 / 1, N=6$, range $18-64 / 1)$, and were represented mainly by the larger sida crystallina and Diaphanasoma prachyurum Those in open areas were mainly the smaller Bosmina longirostris. Benthic macroinvertebrates, consisting mainly of Tricopterans, Chironomids, and worms (gastropods were excluded), were over four times as abundant in vegetated as in open habitats (vegetated $=71 / \mathrm{m}^{2}, \mathrm{~N}=8$, range $39-145 / \mathrm{m}^{2} ;$ open $=17 / \mathrm{m}^{2}, \mathrm{~N}=2$, range $4-26 / \mathrm{m}^{2}$ ). Mortality rates of juvenile bluegills were significantly higher in open water than in vegetated areas (log rank test, $\chi_{\mathrm{df}=1}^{2}=9.06, \quad \mathrm{P}=0.002 ;$ Fig. 2). 


\section{DISCUSSION}

\section{competition}

Presence of similar Lepomis species had no effect on growth or lipid content of fuvenile bluegills; thus, competitive effects from these two species were negligible. If lack of interspecific competitive effects on bluegilis was due to reduced densities of potential competitors as a result of heavy predation, then that suggests lethal effects of predators act to reduce competition in Par Pond; however, densities in the experiment were not reduced, and lack of interspecific competitive effects due to predation seems unlikely. At least three other possibilities exist. First, spotted sunfishes and warmouths may have different niches from bluegills; thus, these species would not compete with bluegills at any density. Informal sampling and diet studies in the literature suggest that fuvenile bluegills, spotted sunfishes, and warmouths consume many of the same prey items (M. Belk pers. Obs., Beisser 1978, Larimore 1957). Typically, uvenile sunfishes show broad overlap in diet among species, even though as adults they show more dietary specialization (Mittlebach 1984, Keast 1980). Bluegills, spotted sunfishes, and warmouths all occupied similar vegetated refuge areas. Given these similarities, competition between these species seems likely. Second, competitive effects may be asymmetric; bluegills may competitively affect spotted sunfishes and 
warmouths, but blueglils may not be affected by other species. Bluegills are known to be dominant competitors with other sunfishes, and they often greatly outnumber other species of Lepomie (M1ttlebach 1988, Osenberg et al. 1992). Thus, lacis of competitive effects from spottad sunfishes and warmouths may be due more to the characteristics of blueglils than to the effect of predators on densities of other species of sunfishes.

Third, lack of effects may be an artifact of the relatively small scale of experimental enclosures. Since some sunfish prey organisms are found in the water column (e.g., zooplankton), and could possibly move through netting on enclosures, resources in enclosures may be only temporarily depressed in high density treatments, leading to an underestimate of total competitive effects. However, given the high densities of fish in some treatment combinations, it seems unlikely that lack of detectable competitive effects is entirely due to possible underestimation of effects.

Growth of bluegills was negatively affected by increased density of conspeciflcs. However, at low densities bluegill growth rates were high relative to that in other reservoirs. Thus, intraspecific competition also appears to have ilttle effect on fuvenile bluegilis in Par Pond, supporting the ldea that abundant predators decrease the potential for competition. 
Conversely, in systems where predators are less abundant, nonlethal effects of predators on fuvenile bluegills result in increased densities and decreased growth (Werner et al. 1983, Mittlebach 1988, Werner and Hall 1988). The direction and magnitude of effects of predators on growth of prey appear to depend on abundance and size of predators.

Why might the effect of predation be dependent on predator abundance? Previous studies suggest that bluegilis respond behaviorally to riek of predation even when predators are relatively small or rare and actual mortality due to predators is low (Werner et al. 1983, Mittlebach and Chesson 1987). However, predators must be relatively abundant to have a strong enough effect on prey mortality to reduce densities of prey. When predatore are abundant, strong lethal effects of predators eclipse the influence of nonlethal effects on prey growth, even though prey still respond behavinrally to predators. In summary, interaction between lethal and nonlethal effects of predators on prey leads to a relationship where the influence of nonlethal effects of predators predominates at low to moderate predator densities, but the influence of lethal effects are more important at high predator densities. 
Growth in open ys, vegetated habitats

Typically, vulnerable size classes of elsh occupy refuge habitats in the presence of predators (Fraser and Cerr1 1982, Werner et al. 1983, Mittlebach 1984, Power 1984, Power et al. 1985, Mittlebach and Chesson 1987, Schlosser 1987). In previous studies, growth of bluegill in refuge habltats was lower than that achleved in open habitat's occupled in the absence of predators (Werner at al. 1983, Werner and Hall 1988), presumably due to increased competition in refuge habitate (M1ttlebach 1988). In contrast, growth of bluegills in par pond was higher in refuge habitate than in risky habltats. Even though bluegill. occupied vegetated refuge areas, (presumably because mortallty rates were lower) density of bluegills was low and competition appeared to be unimportant. High growth rates in refuge habitats suggest a strong lethal effect (but negligible consequences of nonlethal effects) of predators on growth of fuventle bluegills in Par Pond.

\section{Lipld levela}

Growth rates of fuvenile bluegills were affected by density of conspecifics and habitat in these experiments. Unlike growth rates, percent lipid content of juvenile bluegills was unaffected by treatments. In a relatively constant environment with abundant size-specific predators where increases in size decrease mortality from predators, 
growth would be of greater survival value than lipid storage. If resource avallablilty is relatively constant, fuveniles should allocate energy directly to growth rather than to storage, because of the metabolic cost involved in transferring energy from one form to another. On the other hand, if resource avallablitity is veriable, and times of resource abundance do not correspond to times of energy need, then energy storage in the form of lipids may be selected to respond to changes in resource availability.

Although Par Pond recelved thermal effluent during most of its history, water level fluctuations were minimal and populations of most fleh species appear to have been stable over the last 25 years (Paller and saul 1985). Thermal effluent possibly increased resource avallability in one arm of the reservolx, but perlods of low resource avallability probably did not occur (wilde 1985). Consequently, bluegills in Par Pond probably experienced a relatively constant level of resource avallablitty. As has been suggested before (Werner and Gilliam 1984), in such systems, growth is probably the best indicator of competitive effects. However, in systems exhibiting high variance in resource avallability, lipld levels could be more important than growth rate as an indicator of competitive effects. 


\section{ACKNOWLEDGMENTS}

I am indebted to many people for help in performing these experiments. D. Winkelman, S. McAlpine, Y. Van Alstine, C. Tuckfield, C. Lydeard, P. Solberger, and J. Wallin all gave much needed assistance in the field. $P$. Dixon and $C$. Tuckfield helped with statistical analyses. M. Smith, G. Meffe, J. Congdon, R. Warren, R. Pulliam, and J. Gilliam provided helpful reviews of the manuscript. This research was supported by contract DE-ACO9-76SROO-819 from the U.S. Department of Energy to the Savannah River Ecology Laboratory, and was based on work performed in the Laboratory Graduate Participation Program under contract number DE-AC05-760R00033 between the U. S. Department of Energy and Oak Ridge Associated Universities.

\section{LITERATURE CITED}

Beisser, G.S. 1978. Feeding behavior of subadult bluegill

(Lepomis macrochirus) in a reactor cooling reservoir. Master's thesis, University of Georgia, Athens, Georgia, USA.

Bennett, D.H., and R.W. McFarlane. 1983. The fishes of the Savannah River Plant: national environmental research park. SRO-NERP-12, U. S. Department of Energy, Washington D.C., USA. 
Brown, A. V., M. D. Schramm, and P. P. Brussock. 1987. A vacuum benthos sampler suitable for diverse habitats. Hydrobiologia 153:241-248.

Campana, S. E. 1990. How reliable are growth backcalculations based on otoliths? Canadian Journal of Fisheries and Aquatic Sciences 47:2219-2227.

Christie, W.W. 1982. Lipid Analysis. Pergamon Press, Oxford, UK.

Forsythe, T.D., and W.B. Wrenn. 1979. Predator-prey relationships among walleye and bluegill. Pages 475482 in H. Clepper, editor. Predator-Prey systems in Fisheries Management. Sport Fishing Institute, Washingtion D.C.

Fraser, D. F., and R. D. Cerri. 1982. Experimental evaluation of predator-prey relationships in a patchy environment: consequences for habitat-use patterns in minnows. Ecology $63: 307-313$.

Gibbons, J. W., and D. H. Bennett. 1971. Abundance and local movement of largemouth bass (Micropterus salmoides) in a reservoir receiving heated effluent from a reactor. Pages 524-527 in D. J. Nelson, editor. Radioecology, Proceedings of the Third National Symposium on Radioecology. Oak Ridge National Laboratories. CONF-710501-P1, Oak Ridge, Tennessee, USA. 
Haake, P. W., C. A. Wilson, and J. M. Dean. 1981. A technique for examination of otoliths by SEM with application to larval fishes. Pages 12-15 in C. F. Bryan, J. V. Conner, and F. M. Truesdale editors. Proceedings of the 5th Annual Larval Fish Conference. LSU Press, Baton Rouge, Louisiana, USA.

Hairston, N. G., F. E. Smith, and L. E. Slobodkin. 1960. Community structure, population control, and competition. American Naturalist 94:421-425.

Keast, A. 1980. Food and feeding relationships of young fish in the first weeks after the beginning of exogenous feeding in Lake Opinicon, ontario. Environmental Biology of Fishes 5:305-314.

Kotler, B. P., and R. D. Holt. 1989. Predation and competition: the interaction of two types of species interactions. Oikos 54:256-260.

Larimore, R.W. 1957. Ecological life history of the warmouth (Centrarchidae). Bulletin, Illinois Natural History Survey $27: 1-83$.

Menge, B. A., and J. P. Sutherland. 1987. Community regulation: variation in disturbance, competition, and predation in relation to environmental stress and recruitment. American Naturalist 130:730-757.

Miller, T. E., and W. C. Kerfoot. 1987. Redefining indirect effects. Pages 33-37 in W. C. Kerfoot and A. Sih editors. Predation: direct and indirect impacts on 
aquatic communities. University Press of New England, Hanover, New Hampshire, USA.

Mittlebach, G. G. 1984. Predation and resource

partitioning in two sunfishes (Centrarchidae). Ecology $65: 499-513$.

----. 1986. Predator-mediated habitat use: some consequences for species interactions. Environmental Biology of Fishes 16:159-169.

----. 1988. Competition among refuging sunfishes and effects of fish density on littoral zone invertebrates. Ecology $69: 614-623$.

Mittlebach, G. G., and P. L. Chesson. 1987. Predation risk: indirect effects on fish populations. Pages 315332 in W. C. Kerfoot and A. Sih editors. Predation: direct and indirect impacts on aquatic communities. University Press of New England, Hanover, New Hampshire, USA.

Osenburg, C.W., G.G. Mittlebach, and P.C. Wainwright. 1992. Two-stage life histories in fish: the interaction between juvenile competition and adult performance. Ecology $73: 255-267$.

Paller, M. H., and B. M. Saul. 1985. Final report on the adult fish and icthyoplankton of Par Pond and Pond B: January 1984 - June 1985. Report DPST-85-791, E. I. du Pont de Nemours and Company, Savannah River Laboratory, Aiken, South Carolina, USA. 
Power, M. E. 1984. Depth distributions of armored catfish: predator induced resource avoidance? Ecology 65:523528 .

Power, M. E., W. J. Matthews, and A. J. Stewart. 1985. Grazing minnows, piscivorous bass and stream algae: dynamics of a strong interaction. Ecology 66:14481456 .

SAS Institute Inc. 1985. SAS User's Guide:statistics, Version 5 Edition. Cary, North Carolina, USA.

Schlosser, I. J. 1987. The role of predation in age- and size-related habitat use by stream fishes. Ecology $68: 651-659$.

Schultz, D. L., and R. S. Taylor. 1987. Preparation of small otoliths for microscopic examination. North American Journal of Fisheries Management 7:309-311.

Sih, A. 1987. Predators and prey lifestyles: an evolutionary and ecological overview. Pages 203-224 in W. C. Kerfoot and A. Sih editors. Predation: direct and indirect impacts on aquatic communities. University Press of New England, Hanover, New Hampshire, USA.

Sih, A., P. Crowley, M. McPeek, J. Petranka, and K. : ohmeier. 1985. Predation, competition, and prey communities: a review of field experiments. Annual Review of Ecology and systematics 16:269-311. 
Swingle, H.S. 1951. Relationships and dynamics of balanced and unbalanced fish populations. Bull. Ala. Agric. Exp. stn. $274: 1-62$.

Werner, E. E., and D. J. Hall. 1988. Ontogenetic habitat shifts in bluegill: the foraging rate-predation risk trade-off. Ecology 69:1352-1366.

Werner, E. E., and J. F. Gilliam. 1984. The ontogenetic niche and species interactions in size-structured populations. Annual Review of Ecology and systematics $15: 393-425$.

Werner, E. E., J. F. Gilliam, D. J. Hall, and G. G. Mittelbach. 1983. An experimental test of the effects of predation risk on habitat use in fish. Ecology $64: 1540-1548$

Wilde, E.W. 1985. Compliance of the Savannah River Plant P-reactor cooling system with environmental regulations. Report DP-1708, E. I. du Pont de Nemours and Co., Savannah River Laboratory, Aiken, South Carolina, USA. 
Table 1. Sample sizes (number of enclosures), means, and $95 \%$ confidence intervals (UCL $=$ upper $95 \%$ confidence limit, LCL $=$ lower $95 \%$ confidence $1 \mathrm{jmlt}$ ) of bluegill growth (in $\mathrm{mm}$ ) and percent dry weight lipid content in the presence and absence of possible interspecific competitors (spotted sunfish and warmouth; Experiment 1). The experiment lasted for 75 days.

\begin{tabular}{lllllll}
\hline Variable & Treatment & $N$ & Mean & UCL & LCL \\
Presence & 16 & 10.32 & 11.24 & 9.49
\end{tabular}

Growth

$\begin{array}{lllll}\text { Absence } & 16 & 10.13 & 11.02 & 9.31 \\ \text { Presence } & 16 & 4.64 & 5.25 & 4.10\end{array}$

Percent lipid

$\begin{array}{lllll}\text { Absence } & 16 & 3.93 & 4.45 & 3.48\end{array}$


Table 2. Sample sizes (number of enclosures), means, and 95\% confidence intervals (UCL = upper $95 \%$ confidence limit, $L C L=$ lower $95 \%$ confidence 1 imit) of bluegill growth (in mm) and percent dry weight lipid content in open versus vegetated habitats (Experiment 2). The experiment lasted 75 days.

Variable Habitat N Mean UCL ICL

Open $6 \quad 7.42$ 8.88 5.96

Growth

Vegetated

Open

Percent lipid $\begin{array}{llll}8 & 10.24 & 11.47 & 9.02\end{array}$

$\begin{array}{llll}6 & 2.99 & 3.86 & 2.31\end{array}$

$\begin{array}{llll}8 & 4.04 & 5.03 & 3.25\end{array}$ 
Fig. 1, a) Means (and 958 confidence intervals) of growth (in $\mathrm{mm}$ ) of bluegill stocked at four densities. Increased density of bluegill significantly decreased growth rates $\left(F_{3,19}=16.08, \quad P=0.0001\right)$. b) Means (and 958 confidence intervals) of percent lipid content of bluegill stocked at four densities. Density of bluegill had no significant effect on percent lipid content $\left(F_{3,21}=0.23, P=0.87\right)$. 

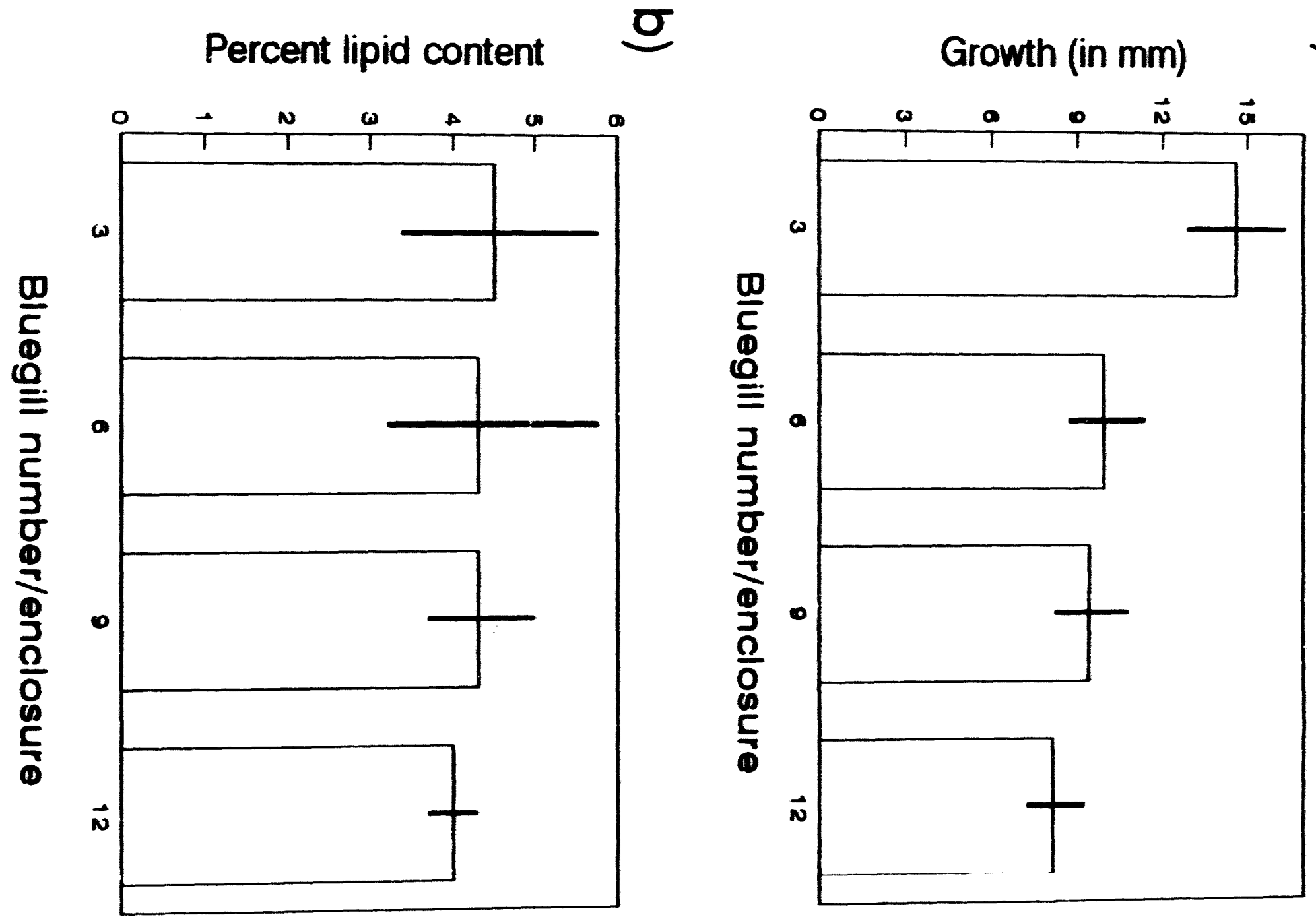
Fig. 2, Plot of cumulative mortality of fuvenile bluegill in open versus vegetated habitats. Mortality was significantly higher in open habitats (log rank test, $\chi_{\text {df }-1=9.06,}^{2}=0.002$ ). 


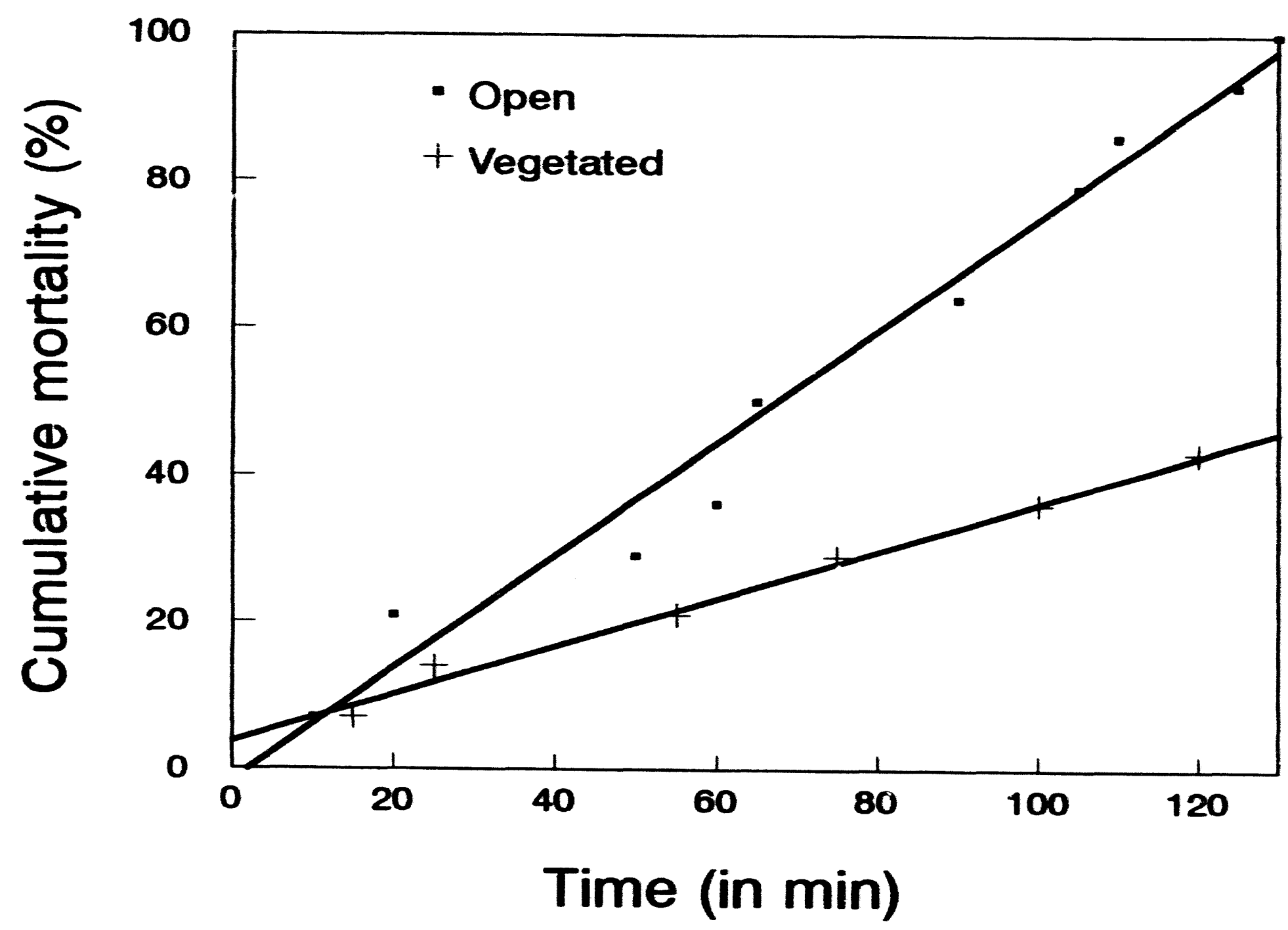


variation in growth and age at maturity in bluegill sunfish (Lepomis macrochtrue): genetic or environmental effects?' Blology.

'Belk, M.C. To be submitted to Journal of Evolutionary 
Key Words: life history, predation, age/size at maturity, bluegill, Lepomis macrochirus, common-garden experiments, plasticity.

10-Year Index: effects of predation on life history, environmental versus genetic influence on age at maturity, plasticity in growth of bluegills.

\section{INTRODUCTION}

Phenotypic differences in life-history characteristics observed among populations can result from genotypic variation and/or from the effect on a plastic phenotype of variation in the environment. Genotypic differences can arise as a result of adaptation to local selective pressures that vary among populations (Endler 1986). However, in environments where selective pressures are variable in direction and magnitude, plastic phenotypes that respond to the immediate environment can be favored selectively (Caswell 1983, Kaplan and Cooper 1984, Via and Lande 1985). Determining whether observed variation in life history traits is attributable to genetic or environmental variation, or both, is an important question in evolutionary biology (Endler 1986).

This study was designed to determine if differences in growth pattern and age and size at maturity between two populations of bluegill sunfishes (Lepomis macrochirus) are the result of detectable genetic differences or are caused 
mainly by differences in environmental variables. I compared characteristics of a population of bluegills from a local hatchery (representative of bluegill populations in public reservoirs in the southeastern U.S.) to characteristics of a population from Par Pond, a nuclearreactor cooling reservoir located on the Savannah River site (near Aiken, South Carolina, U.S.) that is not open to public fishing.

\section{Characteristics of Bluegill Populations}

Bluegills are found in nearly all fresh waters in the southeastern U.S. (Carlander 1977). Typically, in southeastern U.S. reservoirs, bluegills mature at ages 1-2 at about 75-120 $\mathrm{mm}$ total length, and their growth rate gradually decreases with age. In contrast, Par Pond bluegills mature at ages $3-4$ at about 180-200 $\mathrm{mm}$ total length (Belk and Hales unpubl. ms.). Bluegills in Par Pond grow at a relatively constant, rapid rate until they reach about 230-240 $\mathrm{mm}$ total length, after which little growth occurs. The result is a two-phase growth pattern distinctly different from the typical pattern of growth seen in other bluegill populations (Belk and Hales unpubl. ms.).

In most southeastern reservoirs, adult bluegills are exploited heavily; the median of maximum age in samples from 31 reservoirs was age 5 (range $3-7$ ). Largemouth bass (Micropterus salmoides), the major natural predator of 
juvenile bluegills in the southeastern U.S., also are exploited heavily by fishermen, leading to decreased levels of predation on juvenile bluegills by bass. In contrast, Par Pond has never been open to public fishing; maximum ages in two independent samples of bluegills were 9 and 11 . Largemouth bass in Par Pond are about 3-4 times more abundant and 10-30\% larger on average than bass in public reservoirs. The abundant predator population in Par Pond has a strong effect on juvenile bluegills, reducing densities and precluding intraspecific competition (Belk and Hales unpubl. ms., Belk unpubl. ms.).

Bluegill populations described above experienced differing patterns of size-selective predation. In public reservoirs, large bluegills were selectively exploited; whereas, in Par Pond, small bluegills were selectively consumed by predators. Such selection, theoretically, could have led to genetically based differences in growth and age at maturity among populations. To investigate the possibility of genetically based differences among populations I tested the null hypothesis that there was no detectable difference in growth rate or age at maturity between bluegill populations when raised in a common environment. If I observed differences among populations, when they were raised in a common environment, then that would be evidence to reject the null hypothesis and conclude that at least some of the observed variation must have a 
genetic basis. Conversely, if there were no observable differences among populations raised in a common environment, I could not reject the null hypothesis, and would conclude that there was no detectable genetic difference among populations for the traits of growth and age at maturity. Thus, phenotypic variation must be mostly due to variation in the environment. Because growth and age at maturity often are correllated in fishes, I tested both separately using a "common-garden" design.

MATERIALS AND METHODS

Bluegill strains and spawning

Three strains of bluegills were used in this study; Par Pond bluegills, bluegills from a local state-operated hatchery (Glenmore State Fish Hatchery, Newberry, SC), and a cross between the two. Par Pond bluegills were derived from extant populations in the Lower Three Runs drainage at the time the Par Pond reservoir was constructed in the mid1950s. Bluegill populations in Par Pond have been minimally affected by fishing (although some bluegills have been removed from Par Pond by researchers, and trespassers).

To represent the bluegill phenotype typical of public reservoirs in the southeastern U.S., I chose bluegill from a local hatchery. The hatchery population was derived from, and has been periodically augmented, by local wild populations of bluegills. In turn, bluegills from the 
hatchery have been widely distributed in surrounding reservoirs (J. Logan, South Carolina Wildlife and Marine Resources Department, pers. commun.). At the hatchery, bluegills are maintained in large earthen ponds, and are allowed to spawn freely. Bluegills from the hatchery exhibit the phenotype of early maturity and slower growth typical of bluegills in local reservoirs. Given the widespread mixing of stocks between the hatchery and local reservoirs, and the other similarities noted above, the hatchery population appeared to be a good representation of bluegill from public reservoirs.

Three similar, earthen ponds (about $260 \mathrm{~m}^{2}$ surface area and, about $2 \mathrm{~m}$ maximum depth), located less than $100 \mathrm{~m}$ apart near the main laboratory of the Savannah River Ecology Laboratory on the Savannah River Site, Aiken Co. S.C., were used to spawn and rear bluegills for experiments. Ponds were filled with water in February 1991 and about $50 \mathrm{~kg}$ of plant material (leaves and grass clippings) was added to each. Zooplankton collected from local natural ponds were added to each pond in mid-February. During March 1991 adult bluegills were collected from Par Pond by angling, and in April 1991 adult bluegills were obtained from the hatchery. six individuals of each sex were stocked in each pond. Only large adults were used, so sex could be reliably determined from coloration (Carlander 1977). One pond contained only Par Pond fish, a second contained only hatchery fish, and 
the third contained males from Par Pond and females from the hatchery.

Bluegills spawned in experimental ponds in early May, and periodically throughout the remainder of the summer. Bluegill fry and fingerlings produced in the ponds were used in experiments.

\section{Growth Experiment 1}

The first experiment was designed to determine if there were detectable differences in growth rates among strains of bluegills. A "common-garden" approach was used to minimize variance in the phenotype due to environmental variation. A $2 \times 3$ factorial, randomized block design was used with two food levels, three strains of bluegills, and 10 replicates.

\section{Bluegills were housed in individual containers during} the experiment. Containers (made from 4 l plastic milk jugs) had two holes cut in the sides covered with fiberglass screen ( $1 \mathrm{~mm}$ mesh) to allow water flow, and clean white sand was added as substrate (about $2 \mathrm{~cm}$ depth). Containers had open tops, and were placed in $2.5 \mathrm{~m}$ diameter wading poois filled with water to about $20 \mathrm{~cm}$ depth. A small, constant flow of water was added to pools to control temperature fluctuations and maintain water quality, and water level was maintained by punching drain holes in the side of the wading pools at the desired depth. sixty containers were placed in 
two wading pools with five rows of six in each pool. Pools were treated as blocks, both high and low ration treatments and all three strains of bluegill were equally represented in each pool, and treatments were completely randomized within pools.

on 3 July 1991 bluegills were seined from stock ponds, measured (standard length in $\mathrm{mm}$ ), and assigned randomly to individual containers. Beginning mean standard length did not differ by strain (F-test, $P>0.05$ ). Fish were fed frozen brine shrimp daily. The low ration treatment (about $0.07 \mathrm{~g}$ ) was calculated to provide slightly more energy than minimum maintenence requirements (Carlander 1977), and the high ration treatment (about $0.45 \mathrm{~g}$ ) was selected to promote rapid growth.

On 5 September 1991 (64 days duration) fish were removed from containers, and standard length (in $\mathrm{mm}$ ) and mass (to nearest $0.001 \mathrm{~g}$ ) were measured. Because of the constant inflow of fresh water, water temperature, dissolved oxygen, or other water quality parameters may have varied across the wading pool. To avoid possible bias from the effect of position of containers relative to water input, distance from the point of water inflow to individual containers was measured for use as a covariate. Growth during the experiment was calculated as ending length minus beginning length. Eighty percent $(48 / 60)$ of the bluegills survived to the end of the experiment. Variances were 
similar across treatment groups, so no data transformation was necessary. Analysis of covariance (ANCOVA) using beginning length and distance to water inflow as covariates was used to analyze treatment effects on growth in length (SAS, GLM procedure; SAS 1985).

A separate analysis (ANCOVA), using the same independent variables and covariates, was done using gain in mass as the dependent variable. Beginning mass was calculated using a length-weight regression for bluegills of the same size from experimental populations. Results of the analysis on mass were similar in all respects to the analysis on length, so only the results from the length analysis are reported here.

\section{Growth Experiment 2}

The objective of the second growth experiment: was the same as the first experiment: to determine if there were detectable differences in growth rate among strains of bluegills. However, the second experiment was designed to provide a more natural environment in which to test for differences in growth. Groups of bluegills were placed in large enclosures located in earthen ponds. The enclosures allowed greater space for individual movement, access to natural food items found in the water column, and social interaction, none of which were possible in Experiment 1 . A $2 \times 3$ full factorial, randomized block design was used with 
two densities of bluegills ( 3 or 12 /enclosure), three strains of bluegills (as described above), and 6 replicates/treatment.

Enclosures measured $1.6 \mathrm{~m}$ on a side, enclosed about 2.5 $\mathrm{m}^{2}$ surface area, and were composed of frames made of PVC pipe $(3.2 \mathrm{~cm}$ diameter) covered with $3 \mathrm{~mm}$ mesh nylon netting on four sides and the bottom. Enclosures were placed in three ponds (ponds were treated as blocks) with twelve enclosures/pond. Water level in enclosures was kept at about $1.2 \mathrm{~m}$ depth by tethering enclosures to the shore at the desired depth and attaching a large piece of styrofoam material (about $30 \times 50 \times 100 \mathrm{~cm}$ ) to the side of the enclosure to aid in flotation.

Fish were photographed and placed in enclosures on 15 August 1991. Standard length was measured from photographs (a scale was included in each photograph) to reduce handing of fish. Beginning mean standard length did not differ by strain $(F-t e s t ~ P>0.05)$. About $4.5 \mathrm{~g}$ of commercial fish chow per enclosure was added daily to supplement available food resources. Fish were removed from enclosures on 2 December 1991 (110 days duration), and standard length was recorded. Growth was calculated as ending standard length minus beginning standard length. Survivorship was $88.5 \%$ $(239 / 270)$. Gxowth was log-transformed to stabilize variances among treatment groups. Analysis of covariance (ANCOVA) was used to analyze effects of treatments on 
growth, with mean beginning length as the covariate (SAS, GLM procedure; SAS 1985).

\section{Beproduction Experiment}

The purpose of this experiment was to determine whether differences in age at maturity between Par Pond and hatchery bluegill populations were detectable in a common environment. Groups of bluegills were placed in the same enclosures used in the second growth experiment, and the proportion of the sample that matured at age one was considered an appropriate measure of age at first reproduction. A high proportion (>0.5) of individuals maturing at age 1 would be typical of the pattern of early maturity seen in public reservoirs, whereas, a small proportion (e.g., <0.2) of individuals maturing at age 1 would indicate the delayed reproduction phenotype as seen in Par Pond. A randomized block design with the three strains of bluegills as treatments, and ponds treated as blocks was used for this experiment; treatments were replicated nine times. Enclosures were arranged the same way as in the second growth experiment, except there were only nine enclosures per pond.

Three bluegills were photographed and placed in each enclosure on 11 March 1992. Beginning standard length was measured from photographs for use as a covariate. Beginning mean standard length did not differ by strain (F-tests, $P>$ 
$0.05)$. About $10 \mathrm{~g}$ of commercial fish chow per enclosure was added daily to supplement available food resources. Bluegills were removed from enclosures on 1 May 1992, measured (standard length), welghed (to nearest $0.01 \mathrm{~g}$ ), and their gonads removed. Gonads were weighed (to nearest 0.01 g) and scored as reproductive or non-reproductive based on their physical appearance (James 1946, Snyder 1983).

\section{RESULTS \\ Growth Experiments}

Growth of bluegills in the first experiment did not vary significantly among bluegill strains $\left(F_{2,39}=0.75, P=0.48\right.$; Fic. 1). Growth was significantly affected by food ration $\left(F_{1,39}=943.6, P=0.0001 ;\right.$ Fig. 1), and by the covariate beginning length $\left(F_{1,39}=4.62, P=0.038\right)$. Interaction between strain and ration was not significant $\left(F_{2,39}=0.18, P=0.84\right)$, and the covariate, distance to water input, was not significant $\left(F_{1,39}=0.43, P=0.52\right)$.

Resuits of the second experiment were similar to the first. Growth of bluegills did not vary significantly among strains $\left(F_{2,26}=2.07, P=0.15 ;\right.$ Fig. 2$)$, but was significantly affected by density of bluegills $\left(F_{1,26}=91.6, P=0.0001 ;\right.$ Fig. 2). Interaction between strain and density was not significant $\left(F_{2,26}=0.16, P=0.85\right)$, and the covariate, mean beginning length, was not significant $\left(F_{1,26}=0.22, P=0.64\right)$. 


\section{Reproduction Experiment}

Ninety-one percent $(74 / 81$; of the fish were recovered at the end of the experiment. Nearly all fish had mature gonads (Par Pond $=84 \%$ mature, hatchery $=100 \%$ mature, cross $=74 \%$ mature), so further statistical analysis was unnecessary. In a common environment, as provided in this experiment, the majority of bluegills from all three strains matured at age 1. Fish that were not mature at the end of this experiment ( 168 in Par Pond sample, and 268 in the cross sample) averaged smaller in length than mature individuals (Fig. 3), and presumably they would have matured at age 2. Accordingly, even though the proportion of individuals maturing at age 1 varied by 268 among samples, the overall pattern still coincides with the typical phenotype expressed by bluegills in public reservoirs in the southeastern U.S.

\section{DISCUSSION}

There were no detectable differences in growth rates or age at maturity among bluegills from Par Pond, those from the hatchery, and those from the cross when raised in a common environment. Accordingly, the initial null hypothesis of no detectable variation in a common environment cannot be rejected. Thus, variance in growth pattern, and age and size at maturity observed between 
populations apparently resulted mostly from environmental differences, not genetic variation, between populations. Because the above experiments were performed on juvenile bluegills during their first year, the possibility exists that genetically variant growth patterns may not be evident until later in life. Jennings and Philipp (1992b) observed that growth trajectories of longear sunfishes from different populations did not diverge until after fish matured in their second year. However, in their experiment fish from different populations matured at different times (Jennings and Philipp 1992b). In fishes, allocation of limited resources produces a marked trade-off between growth and reproduction, resulting in a decline in growth rate after maturation (Alm 1959, Gross and Charnov 1980, Roff 1983, Deacon and Keast 1987, Reznick 1990, Jennings and Philipp 1992b). Thus, it seems unlikely that bluegills maturing at the same age and size in a common environment would show divergent growth patterns in later years. Bluegills used in this study appear to exhibit highly plastic phenotypes for age and size at maturity that are determined by factors in the local environment.

What environmental differences might cause observed phenotypic differences in these populations? Age and size at maturity can be affected by at least three environmental factors: 1) resource availability, 2) demographic structure, and 3) size-selective predation. Each of the above factors 
are discussed to see if they are consistent with the observed patterns of variation in age and size at maturity. Resource availability has been shown to influence acje and size at maturity in genetically similar fish (Alm 1959, Fox and Keast 1991, Reznick 1990). Fish given high levels of resources grow rapidly and mature at an early age and large size, whereas fish on low levels of resources grow slowly and mature later at smaller sizes (Reznick 1983, Stearns and Crandall 1984, Reznick and Bryga 1987, Vondracek et al. 1988). Bluegills in Par Pond grow rapidly for the first 3-4 years and attain large size relative to fish from other reservoirs (Belk and Hales, unpubl. ms.). If differences in phenotypes were due to differences in resources and resultant growth rates, bluegills in Par Pond should mature at larger sizes and younger ages than bluegill in other populations. This is clearly not the case, as Par Pond bluegills show delayed maturity (ages 3-4) relative to other populations (Belk and Hales, unpubl. ms.). Thus, possible differences in resource availability do not appear to fully explain the observed differences in growth and age and size at maturity between these populations.

size and age at maturity in some species of fish may be affected by demographic structure (Sohn 1977a, 1977ㅁ, Warner 1984). Specifically, in sunfishes where males construct and defend nests and compete for mates, larger males have increased mating success (Dominey 1980, Gross 1982, Jennings 
and Philipp 1992a). Thus, males that delay reproduction until a relatively large body size is obtained should be most successful in obtaining nest sites and matings. Additionally, in such systems, some small males adopt alternate reproductive b haviors, maturing precociously at small sizes and using tactics such as sneaking and female mimicry to gain reproductive opportunities (Gross 1979, 1982, 1984, Dominey 1980, 1981, Jennings and Philipp 1992ą). Female sizes and ages at maturity do not seem to be constrained by numbers of adult females, and females typically mature at small sizes relative to males (Dominey 1980, Warner 1984, Jennings and Philipp 1992b) .

The bluegill population in Par Pond has a large representation of large adults relative to other reservoirs, probably due to the lack of fishing. Thus, we might expect age at maturity to be delayed by the influence of adult males in Par Pond. Two lines of evidence suggest that demographic structure of the Par Pond bluegill population cannot alone account for the observed pattern. First, female bluegills in Par Pond also exhibit delayed maturity at large size. Possible demographic effects on male age and size at maturity cannot explain the concurrent pattern in females. Second, size-structured competition among males often leads to the development of alternative reproductive strategies among small individuals as described above. There is no evidence for small, early maturing males in Par 
Pond, despite collection of nearly 700 bluegills over a three-year time span, using a variety of techniques. The smallest reproductively active males observed were $>200 \mathrm{~mm}$ total length (Belk and Hales unpubl. ms., Belk unpubl.). Both theoretical and experimental studies provide evidence for a strong influence of size-selective mortality on age and size at maturity and other life history traits (Silliman 1975, Law 1979, Michod 1979). Predation is the most well-studied agent of size-selective mortality in fishes. Predators have been shown to influence life history traits in both ecological and evolutionary ways (Krumholz 1963, Reznick et al. 1990). Reznick and colleagues (Reznick and Endler 1982, Reznick 1982, Reznick and Bryga 1987, Reznick et al. 1990) have shown, through a series of laboratory and field experiments, that life history characteristics of guppies (Poecilia reticulata) evolve in response to size-selective predation. Guppies experiencing selective predation on small size-classes matured later and at a larger size than guppies experiencing selective predation on large size-classes.

The best evidence for phenotypic life history responses in fish to size-selective predation comes from fisheries data on commercially harvested species. Heavily harvested fish populations, where large, mature individuals are removed selectively, show reduced age and size at maturity (Cushing 1972, Le Cren et al. 1972, Regier and Loftus 1972, 
Gwahaba 1973, Spangler et al. 19\%\%). Aquatic snails in the presence of a predator that selectively preyed on smaller individuals, grew larger and matured later than snails in the absence of the predator (Crowl and Covich 1990). Iife history differences in the snails were not genetically based, but rather induced by the presence of the feeding predator.

Largemouth bass in Par Pond, the major natural predator of juvenile bluegills, are about $3-4 \mathrm{X}$ more abundant and 10308 larger than bass in typical public reservoirs in the southeastern U.S. (Belk and Hales unpubl. ms.). Accordingly, bluegills in the presence of this abundant predator population that selectively preys on small fish, would be expected to delay maturity to a size at which mortality rates decrease leading to maturation at a large size and older age in both sexes. Conversely, in typical public reservoirs, predation on small size-classes by largemouth bass is reduced, but predation by humans on large size-classes is increased. Thus, we would expect bluegills to mature early at a smaller size. These predictions match observed differences in growth pattern and age and size at maturity between Par Pond and other systems, suggesting that differences in size-selective predation are the most likely cause. However, large scale experiments, manipulating density and type of predators would be needed to confirm this hypothesis. 
Results reported here showing no genetic differences between populations should not be interpreted to mean that size-selective fishing by humans will have no genetic effect on exploited populations. The possibility exists that populations experiencing different size-selective predation may evolve genetic differences for life history traits given sufficient time. Guppies experiencing different sizeselective predation required 30-60 generations to evolve genetic differences in life history characteristics (Reznick et al. 1990). Allowing an equivalent number of generations, bluegill populations would require 60-180 years of stable selective pressure before genetic differences would be evident. Par pond has been in existance for about 35 years, allowing only about 10-15 birth-maturity generations of bluegills.

\section{ACKNOWLEDGMENTS}

I am indebted to many people for help in performing these experiments. D. Winkelman, s. MCAlpine, C. Lydeard, P. Johns, R. Mazenko, H. Roczak, and A. Cramer all gave much needed assistance in the field. J. Pechmann and W. Gibbons allowed me to use the experimental ponds. J. singleton at the Glenmore State Fish Hatchery, in Newberry, s.c. kindly provided adult bluegills. C. Tuckfield helped with statistical analyses. M. Smith, G. Meffe, J. Congdon, R. Warren, and R. Pulliam provided helpful reviews of the 
manuscript. This research was supported by contract DEACO9-76SRO0-819 from the U.S. Department of Energy to the Savannah River Ecology Laboratory, and was based on work performed in the Laboratory Graduate Participation Program under contract number DE-AC05-760R00033 between the U. S. Department of Energy and Oak Ridge Associated Universities.

\section{LITERATURE CITED}

ALM, G. 1959. Connection between maturity, size, and age in fishes. Rep. Inst. Freshwater Res. Drottingholm $40: 1-145$.

CARLANDER, K.D. 1977. Handbook of Freshwater Fishery Biology, Volume 2. Iowa State University Press, Ames, Iowa.

CASWELL, H. 1983. Phenotypic plasticity in life-history traits: demographic effects and evolutionary consequences. Am. Z001. 23:35-46.

CROWL, T.A., AND A.P. COVICH. 1990. Predator-induced lifehistory shifts in a freshwater snail. Science 247:949951.

CUSHING, D.H. 1972. A history of some of the International fisheries commissions. Proc. R. Soc. Edinburgh, sect. B $73: 361-390$.

DEACON, L.I., AND J.A. KEAST. 1987. Patterns of reproduction in two populations of pumpkinseed sunfish, 
Leponis gibbosus, with differing food resources. Env. Biol. Fish. 19:281-296.

DOMINEY, W.J. 1980. Female mimicry in male bluegill sunfish - a genetic polymorphism? Nature 284:546-548.

-.--. 1981. Maintenance of female mimicry as a reproductive strategy in bluegill sunfish (Lepomis macrochirus). Env. Biol. Fish. 6:59-64. ENDLEP, J.A. 1986. Natural selection in the wild. Princeton Univ. Press, Princeton, NJ, USA. FOX, M.G., AND A. KEAST. 1991. Effect of overwinter mortality on reproductive life history characteristics of pumpkinseed (Lepomis gibbosus) populations. Can. J. Fish. Aquat. Sc1. 48:1792-1799.

GROSS, M.R. 1979. Cuckoldry in sunfishes (Lepomis:

Centrarchidae). Can. J. Z001. 57:1507-1509.

--.-. 1982. Sneakers, satellites and parentals: polymorphic mating strategies in North American sunfishes. Z. Tierpsychol. 60:1-26.

-.--. 1984. Sunfish, salmon, and the evolution of alternative reproductive strategies and tactics in fishes, p. 55-75. In: Fish Reproduction: Strategies and Tactics. R.J. Wootton, and G.W. Potts (eds.). Academic Press, London.

GROSS, M.R., AND E.L. CHARNOV. 1980. Alternative male life histories in bluegill sunfish. Proc. Nat. Acad. Sci., U.S.A. $77: 6937-6940$. 
GWAHABA, J.J. 1973. Effects of fishing on the Tilapia niletica (Linne' 1757) population in Lake George, Uganda over the past 20 years. E. Afr. Wildl. J. $11: 317-328$,

JAMES, M.F. 1946. Histology of gonadal changes in the bluegill, Lepomis macrochirus Rafinesque, and the largemouth bass, Huro salmoides (Lacepede). J. Morph. $79: 63-91$.

JENNINGS, M.J., AND D.P. PHILIPP. 19928. Female choice and male competition in longear sunfish. Behav. Ecol. $3: 84-94$.

JENNINGS, M.J., AND D.P. PHILIPP. 1992b. Reproductive investment and somatic growth rates in longear sunfish. Env. Biol. Fish. (in press).

KAPLAN, R.H., AND W.S. COOPER. 1984. The evolution of developmental plasticity in reproductive characteristics: an application of the "adaptive coinflipping" principle. Am. Nat. 123:393-410.

KRUMHOLZ, L.A. 1963. Relationships between fertility, sex ratio, and exposure to predation in populations of the mosquitofish Gambusia manni Hubbs at Bimini, Bahamas. Int. Revue ges. Hydrobiol. 48:201-256.

LAW, R. 1979. Optimal life histories under age-specific predation. Am. Nat. $114: 399-417$.

LE CREN, E.D., C. KIPLING, AND J.C. MCCORMACK. 1972. Windemere: effects of exploitation and eutrophication 
on the salmonid community. J. Fish. Res. Board Can. $29: 819-832$.

MICHOD, R.E. 1979. Evolution of life historles in response to age-specific mortality factors. Am. Nat. 113:531550.

REGIER, H.A., AND K.H. LOFTUS. 1972. Effects of fisheries exploitation on salmonid communities in oligotrophic lakes. J. Fish. Res. Board Can. 29:959-968.

REZNICK, D.N. 1982. The impact of predation on 11 fe history evolution in Trinidadian gupples: genetic basis of observed life history patterns. Evolution 36:12361250.

---. 1983. The structure of guppy life histories: the tradeoff between growth and reproduction. Ecology $64: 862-873$.

---. 1990. Plasticity in age and size at maturity in male guppies (Roecilita reticulata): an experimental evaluation of ilternative models of development. $J$. Evol. Biol. 3:185-203.

REZNICK, D.A., AND H. BRYGA. 1987. Life-history evolution in gupples (Poecilita reticulata): 1. Phenotypic and genetic changes in an introduction experiment. Evolution $41: 1370-1385$. REZNICK, D.A., H. BRYGA, AND J.A. ENDLER. 1990. Experimentally induced life-history evolution in a natural population. Nature 346:357-359. 
REZNICK, D.N., AND J.A. ENDLER. 1982. The impact of predation on life history evolution in Trinidadian gupples (Poecilie reticulata). Evolution 36:160-177. ROFF, D.A. 1983. An allocation model of growth and reproduction in $\mathrm{fish}$. Can J. Fish. Aquat. Sci. $40: 1395-1404$.

SAS Institute Inc. 1985. SAS User's Guide:Statistics, Version 5 Edition. Cary, North Carolina, USA. SILLIMAN, R.P. 1975. Selective and unselective exploitation of experimental populations of Tilepia moseambica. Fish. Bull. 73:495-507.

SNYDER, D.E. 1983. Fish eggs and larvae, p. 165-197. In: Fisheries Techniques. L.A. Nielson and D.L. Johnson (eds.). American Fisheries Society, Bethesda, Maryland.

SOHN, J.J. 1977a. The consequences of predation and competition upon the demography of Gambusia manni (Pisces:Poecilildae). Copela 1977:224-227.

-.--. 1977b. Socially induced inhibition of genetically determined maturation in the platyfish, Xiphophorus maculatus. Science 195:199-201.

SPANGLER, G.R., N.R. PAYNE, J.E. THORPE, J.M. BYRNE, H.A. REGIER, AND W.J. CHRISTIE. 1977. Responses of percids to exploitation. J. Fish. Res. Board Can, 34:19831988 . 
STIARNS, S.C., AND R.E. CRANDALL. 1984. Plasticity for age and size at sexual maturity: a life-history response to unaviodable stress, p. 13-33. In: Fish Reproduction: Strategies and Tactics. R.J. Wootton, and G.W. Potts (eds.). Academic Press, London.

VIA, S., AND R. LANDE. 1985. Genotype environment interaction and the evolution of phenotypic plasticity. Evolution 39:505-522.

VONDRACEK, B., W.A, WURTSBAUGH, AND J.J. CECH, JR. 1988. Growth and reproduction of the mosquitorish, Gambusia affinis, in relation to temperature and ration level: consequences for life history. Env. Boll. Fish. 21:4557.

WARNER, R.R. 1984. Deferred reproduction as a response to sexual selection in a coral reef fish: a test of the life historical consequences. Evolution 38:148-162. 
Figure 1. Results of Growth Experiment 1 showing mean (and 958 confidence intervals about the mean) growth of bluegills from three experimental populations (Par Pond, hatchery, and a cross between the two) at two different ration levels. Growth did not differ between populations, but was significantly affected by food ration level. Numbers on bars are sample sizes of $f$ ish in the various treatment combinations. They vary as a result of mortality during the experiment. 


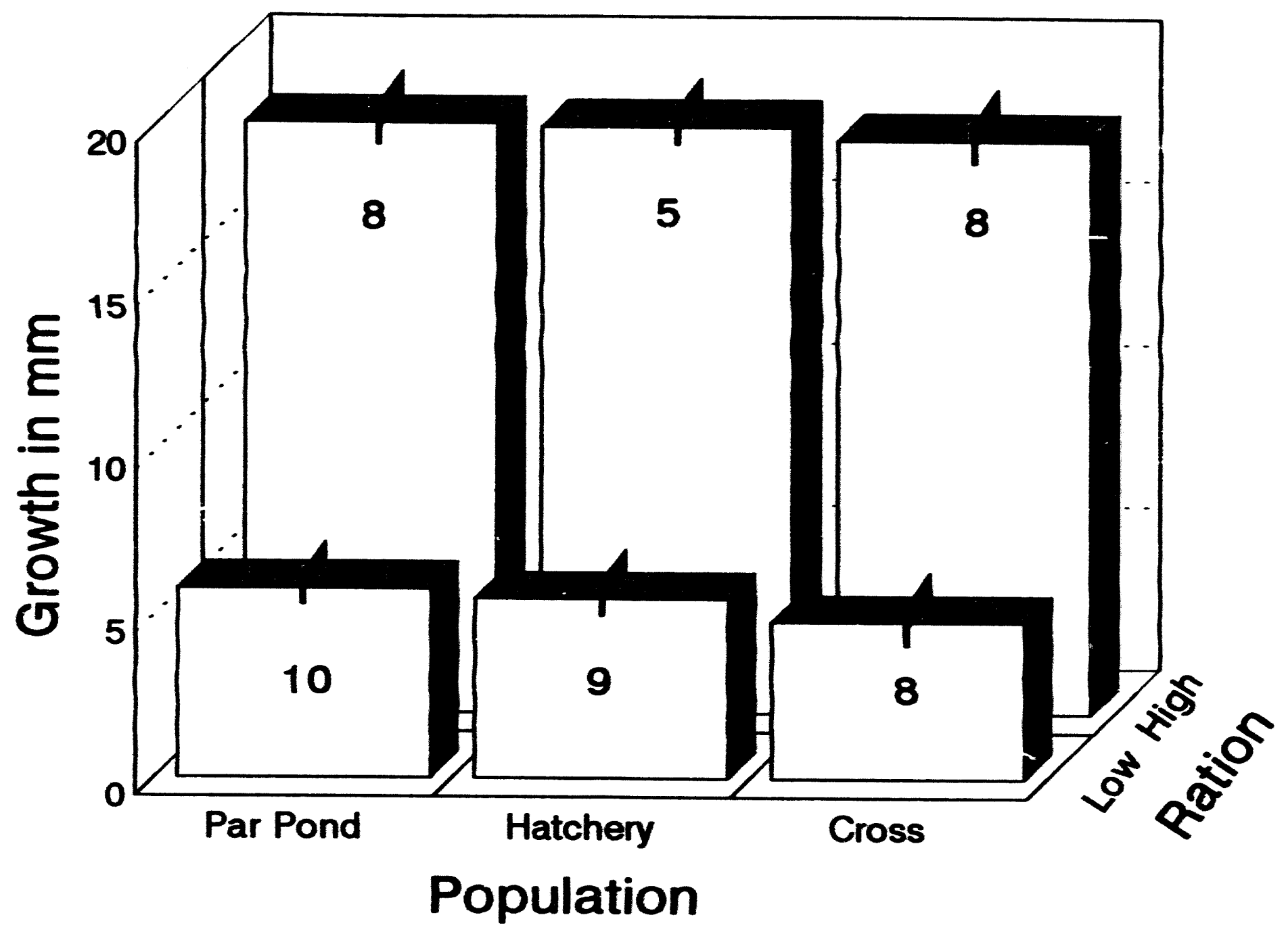


Figure 2. Results of Growth Experiment 2 showing mean (and 95\% confidence intervals about the mean) growth of bluegills from three experimental populations (Par Pond, hatchery, and a cross between the two) at two different densities. Growth did not differ between populations, but was significantly affected by density of bluegills. Numbers on bars are sample sizes of enclosures in the various treatment combinations. They vary as a result of mortality during the experiment. 


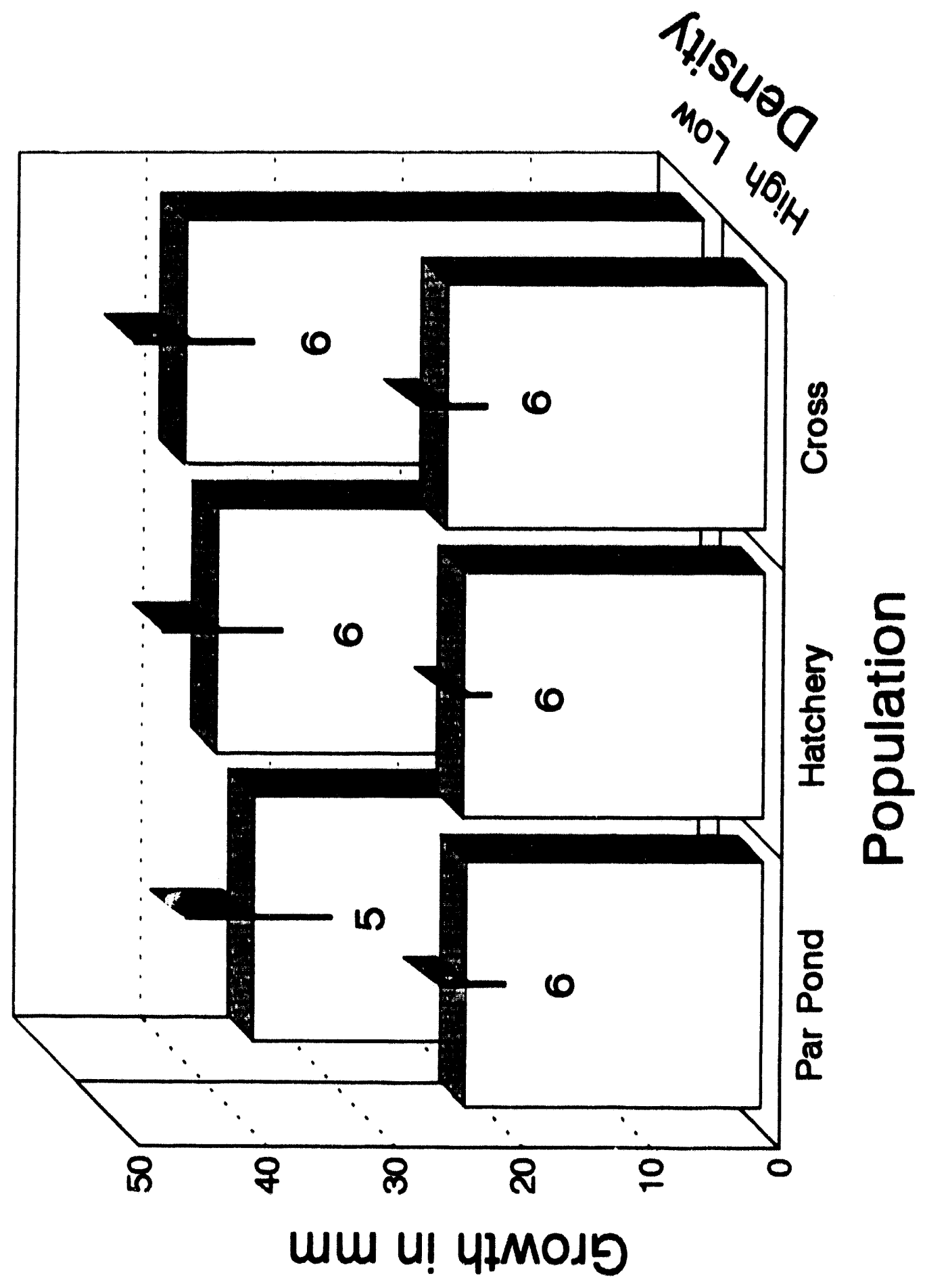


Figure 3. Length-frequency distribution of mature (black bars) and immature (gray bars) bluegills at the end of the reproduction experiment. Immature bluegills average smaller in length than mature bluegills. 


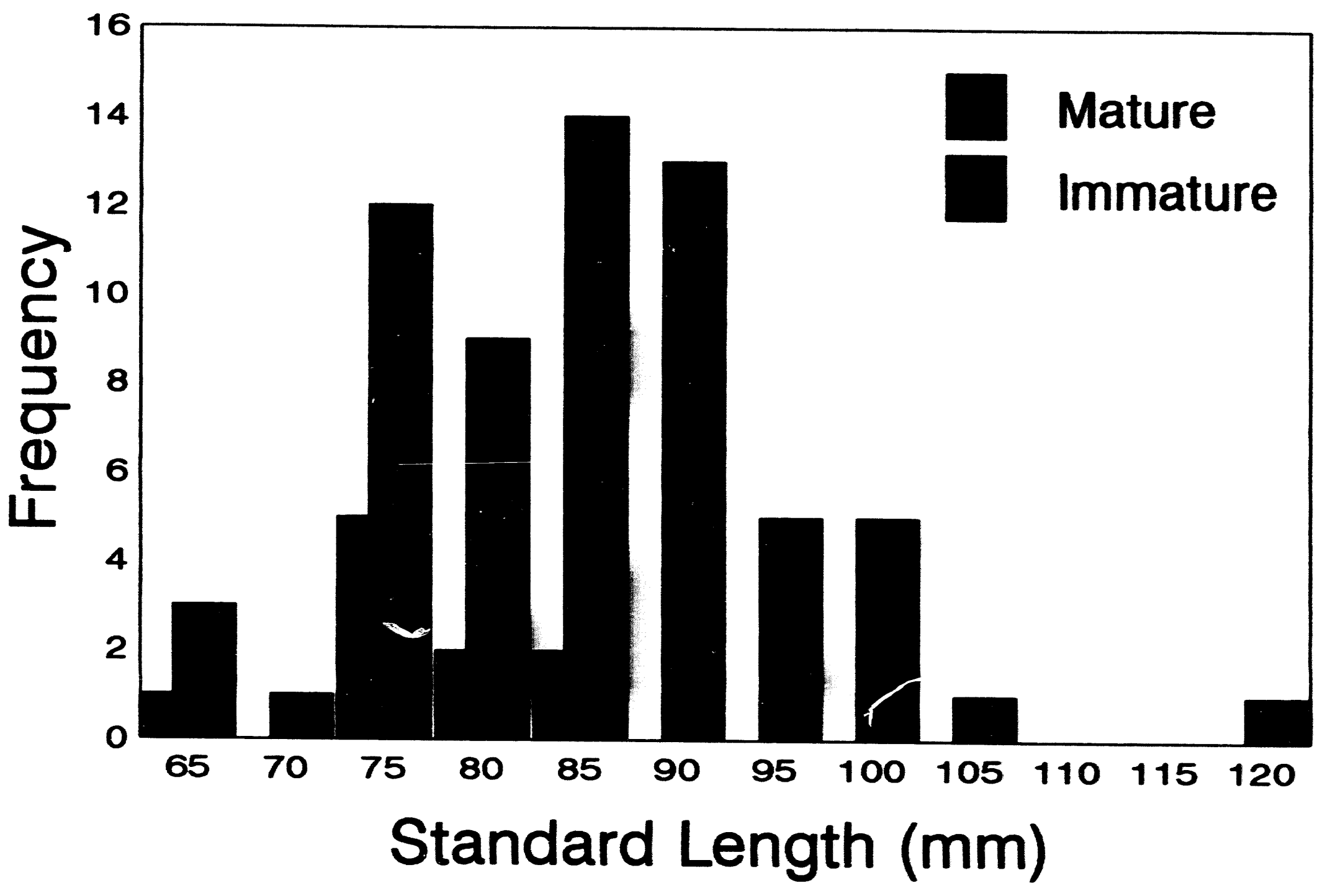




\section{CONCLUSION}

Par Pond is a unique system for the study of effects of predation on fish populations. Because public access to par Pond is restricted, abundant populations of predatory $f$ ish species have developed. These populations are characterized by large size and old age structure typical of unexploited fish populations. In contrast, nearly all other reservoirs and lakes in the U.S. are heavily exploited by public and commercial fishing, with resulting small and young population structure. Previous studies on effects of predation on bluegill populations have mostly been conducted in systems affected by public fishing or experimental ponds that mimic those conditions (e.g., small predator size). This research provides a unique comparison to previous research by providing information on competitive interactions and life history of bluegills experiencing heavy predation. Comparative studies do not provide strong inferences as to the cause of observed differences. However, many species and forms of species interactions do not lend themselves to experimental manipulation (e.g., fish population dynamics in reservoirs). Experimental results from subsystems, or related but more tractable systems may not fully represent processes occurring in the whole system. 
In such cases, corroboration of several comparisons between systems provides the best alternative. In the three studies included in this dissertation, I have used comparisons between bluegill populations in Par Pond and populations in other similar reservoirs. Populations of predators were not manipulated directly; rather, I asked the question "if predators are affecting populations of bluegilis in Par Pond, what patterns might result relative to populations less affected by predators?"

Considering the research in this dissertation as a whole, the following patterns seem noteworthy. 1) At high levels of predation, direct, lethal effects of predators are most important in affecting population dynamics of bluegills. High growth rates, low densities, and lack of detectable competitive interactions all conform to predicted lethal effects of predators. 2) The observed delay in maturity in Par Pond bluegill until large size is attained does not result from genetic differences among populations. Phenotypic differences are best explained by the predicted effects of differences in size-selective predation.

Comparison of this and previous studies suggests that the effect of predators on prey can be either positive or negative and can vary in magnitude depending on the abundance and size structure of the predator population. The realized effect on prey populations depends on the relative magnitude of lethal and nonlethal effects of 
predators. Nonlethal effects appear to be most important at low predator abundances, whereas lethal effects predominate at high predator abundances. Thus, studies that attempt to characterize the effects of predation using a presence/absence design may not reveal the entire range of possible results. 

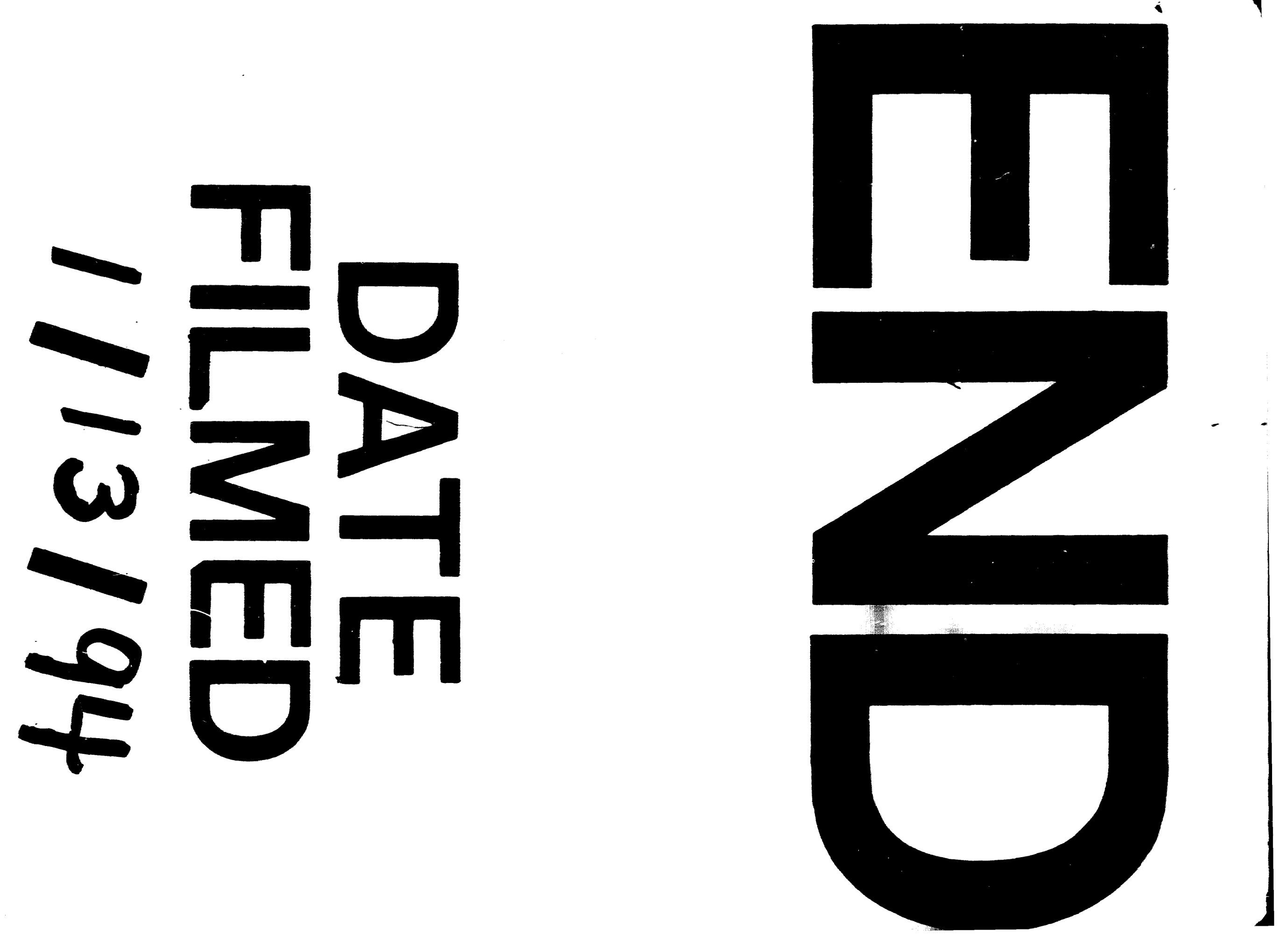
